\title{
EXTRACTION OF METAL IONS \\ WITH N,N-DISUBSTITUTED AMIDES
}

Gene Michael Orf

M.S. Thesis Submitted to Iowa State University

This report was prepared as an account of work sponsored by the United States Government. Neither the United States nor the United States Energy Research and Development Administration, nor any of their employees, nor any of their contractors, their employees, nor any of their contractors, subcontractors, or their employees, makes any warranty, express or implied, or assumes any legal liability or responsibility for the accuracy, completeness

or usefulness of any information, apparatus, product or

process disclosed, or represents that its use would not

infringe privately owned rights.

\author{
Ames Laboratory, ERDA \\ Iowa State University \\ Ames, Iowa 50010
}

Date Transmitted: July 1975

PREPARED FOR THE U.S. ENERGY RESEARCH AND DEVELOPMENT ADMINISTRATION UNDER CONTRACT NO. W-7405-eng-82 


\section{DISCLAIMER}

This report was prepared as an account of work sponsored by an agency of the United States Government. Neither the United States Government nor any agency Thereof, nor any of their employees, makes any warranty, express or implied, or assumes any legal liability or responsibility for the accuracy, completeness, or usefulness of any information, apparatus, product, or process disclosed, or represents that its use would not infringe privately owned rights. Reference herein to any specific commercial product, process, or service by trade name, trademark, manufacturer, or otherwise does not necessarily constitute or imply its endorsement, recommendation, or favoring by the United States Government or any agency thereof. The views and opinions of authors expressed herein do not necessarily state or reflect those of the United States Government or any agency thereof. 


\section{DISCLAIMER}

Portions of this document may be illegible in electronic image products. Images are produced from the best available original document. 
This report was prepared as an account of work sponsored by the United States Government. Neither the United States nor the United States Energy Research and Development Administration, nor any of their employees, nor any of their contractors, subcontractors, or their employees, makes any warranty, express or implied, or assumes any legal liability or responsibility for the accuracy, completeness, or usefulness of any information, apparatus, product or process disclosed, or represents that its use would not infringe privately owned rights.

Available from: National Terhnical Information Service U. S. Department of Commerce P.O. Box 1553 Springfield, VA 22161

Price: Microfiche $\$ 2.25$ 
Extraction of metal tons

with $\mathrm{N}, \mathrm{N}$-disubstituted amides

by

Gene Michael Orf

A Thesis Submitted to the

Graduate Faculty in Partial Fulfillment of

The Requirements for the Degree of

MASTER OF SCIENCE

Department: Chemistry

Major: Analytical Chemistry

Approved:

J. S. Fritz\%s

In Charge of Major. Work

For the Major Department

For the Graduate College

Iowa State University

Ames, Iowa 
TABLE OF CONTENTS

Page

INTRODUCTION

SURVEY OF THE LITERATURE

PRINCIPLES OF SOLVENT EXTRACTION

EXPERIMENTAL

Apparatus

14

Reagents

Preparation of $\mathrm{N}, \mathrm{N}-\mathrm{Dihexylacetamide}$

14

Physical Properties of the N,N-Disubstituted

15 Amides Used

Analytical Techniques

18

Experimental Procedure

18

19

RESULTS AND DISCUSSION

FUTURE WORK

45

LITERATURE CITED

48 


\section{INTRODUCTION}

The usefulness of an organic solvent as an extractant for metal ions depends on the geometry of the solvent and the functional groups that the solvent contains. By varying these parameters, many new and useful solvents can be obtained.

In recent years a great deal of research has been conducted on unionized compounds which coordinate to metal ions through the action of a polar functional group. Among these compounds are the organophosphorous extractants tri-nbutyl phosphate, tri-n-octyl phosphine oxide and bifunctional phosphine oxides $(1,2)$. These compounds owe their coordinating ability to the semi-polar phosphorous-oxygen moiety, $=\mathrm{P} \rightarrow 0$. Another group of compounds in this class are the sulfoxides (3). These compounds owe their coordinating ability to the semi-polar sulfur-oxygen moiety, $s \rightarrow 0$. Solvents of this type, in which the oxygen atom of the solvent molecule coordinates with the metal ion in the solvent extraction system, belong to a group of solvents known as oxonium solvents. N,Ndisubstituted amides, of the general formula ${ }_{R}^{R}-N-\stackrel{C}{C}-R$, also belong to this group and their coordinating ability is due to the semi-polar carbon-oxygen moiety ' $C \rightarrow 0$.

Amides are strong extractants because of the availability of electrons on the oxygen atom for bonding. Using proton affinity as revealed by infrared spectroscopic measurements to evaluate relative basicity, the observed decrease in base 
strength of a series of oxonium solvents follows the order: alcohols, ethers, and ketones (4). Amides are stronger extractants than ketones, but not as strong as tri-n-butyl phosphate. (TBP). However, TBP of ten decomposes to di-n-butyl phosphate which is also an excellent extractant and this makes it difficult to predict which species is the extractant. The thermal stability of amides is comparable to that of TBP and the hydrolytic stability of the amides is about the same as that of TBP (5).

All previous work with amides as extractants has been on the extraction of the nitrates of quadravalent and hexavalent actinides, of zirconium nitrate in nitric acid solution, and of nitric acid itself. The purpose of the present work is to extend the study of the extracting power of amides to several other metal ions from nitrate solution, to study the extracting power of amides on several metal ions from perchlorate solution, in which the mechanism of extraction is entirely different from that of extraction from nitrate solution, and to examine the possible use of amides as reagents for analytical separations. 
SURVEY OF THE LITERATURE

It was first shown by Feder that $N, N$-dibutylacetamide was roughly comparable to tributyl phosphate as an extractant for uranyl nitrate (6). Siddall extended the work of Feder and studied the effects of altering the hydrocarbon substituents of the amide molecule on the extraction of $\mathrm{UO}_{2}{ }^{2+}$, $\mathrm{Pu}(\mathrm{IV}), \mathrm{Pu}(\mathrm{VI}), \mathrm{Np}(\mathrm{VI}), \mathrm{HNO}_{3}, \mathrm{Th}(\mathrm{IV})$, and $\mathrm{Zr}(\mathrm{IV})$ from nitric acid solution (7). He found that the largest effect came from methyl substitution on the $\alpha$-carbon of the amide. In going from acetamide to complete substitution on the $\alpha$-carbon the extraction of $U(V I)$ was only decreased slightly, but the extraction of $\mathrm{Pu}(\mathrm{IV})$ and $\mathrm{Th}$ was reduced by factors of $10^{3}$ to $10^{4}$ and $\mathrm{Zr}$ by several hundred. Substitution of ethyl or longer chains did not have any greater effect on the extraction than the methyl substitution. When formamides were used, the extraction of $\mathrm{Zr}$ was increased but that of $\mathrm{Th}$, $U$, and $\mathrm{Pu}(\mathrm{IV})$ decreased. Branching or bulkiness of the amine substituents had the same effect as branching at the $\alpha$-carbon; but to a much smaller extent and there were some exceptions. Siddall suggested that the uranium complex extracted contained two amide molecules per uranium molecule, the thorium complex contained a small cluster of more than two amide molecules for each metal atom, and the zirconium complex probably involved two amide molecules per zirconium molecule. 
Other studies similar to Siddall's were carried out with similar results $(8,9,10,11,12)$. The conclusions made in these reports on the effect of the structure of the amides on their extracting power were that some of the amides with unbranched alkyl chains had about the same extraction power for thorium and uranium, but branching of the alkyl chains usually causes a greater decrease in thorium and zirconium than in uranium extraction. Thorium extraction was characterized by a strong dependence on the acidity of the aqueous phase, and N,Ndibutylacetamide showed the best extracting power for both uranium and thorium. It was suggested that thorium, uranium, and zirconium could be extracted separately or simultaneously by choosing the appropriate amide structure and nitrate concentration.

The donor properties of amides have been studied extensively. Drago and coworkers performed spectrochemical studies on some lower amide complexes of nickel(I.I) perchlorate and chromium(II) perchlorate $(13,14)$. Infrared spectra of the complexes indicated that the carbonyl oxygen was the donor in all of the complexes. Visible and near-IR spectra as well as elemental analyses indicated that the complexes were six-coordinate octahedral species. Earlier work had shown that the carbonyl oxygen of the amide was a better donor than the carbonyl oxygen of acetone. This was attributed to delocalization of the nonbonding electron pair 
on the nitrogen into a $\pi$-molecular orbital involving oxygen, carbon, and nitrogen. Drago estimated the basicity of the amides from their interaction with phenol to show that the Inductive effects of the $R$ groups contributed to the donor strength of the oxygen. The donor strength was measured from the interaction of the amide with phenol, because the difference in the frequency of the $\mathrm{O}-\mathrm{H}$ stretching vibration of phenol in an adduct compared to free phenol is reported to be linearly related to the enthalpy of adduct formation when phenol complexes with a large number of oxygen and nitrogen donors. The series of increasing donor strength was found to

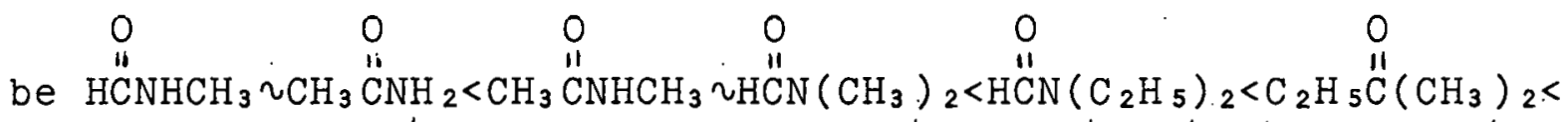
$\mathrm{CH}_{3} \stackrel{\mathrm{CN}}{\mathrm{CN}}\left(\mathrm{CH}_{3}\right)_{2}$. Except for $\mathrm{N}, \mathrm{N}$-dimethylbutyramide, this was the serles predicted on the basis of inductive effect. It was proposed that if $R_{1}$ were an alkyl group and either $R_{2}$ or $R_{3}$ were alkyl, the structure in which $R_{3}$ is alkyl would be favored due to steric hindrance between $R_{1}$ and an alkyl $R_{2}$. When the amides are coordinated to metal ions, a steric repulsion arises between coordinated ligands if $R_{1}$ and $R_{3}$ are both alkyl. The nature of these effects can be seen in Figure 1. 


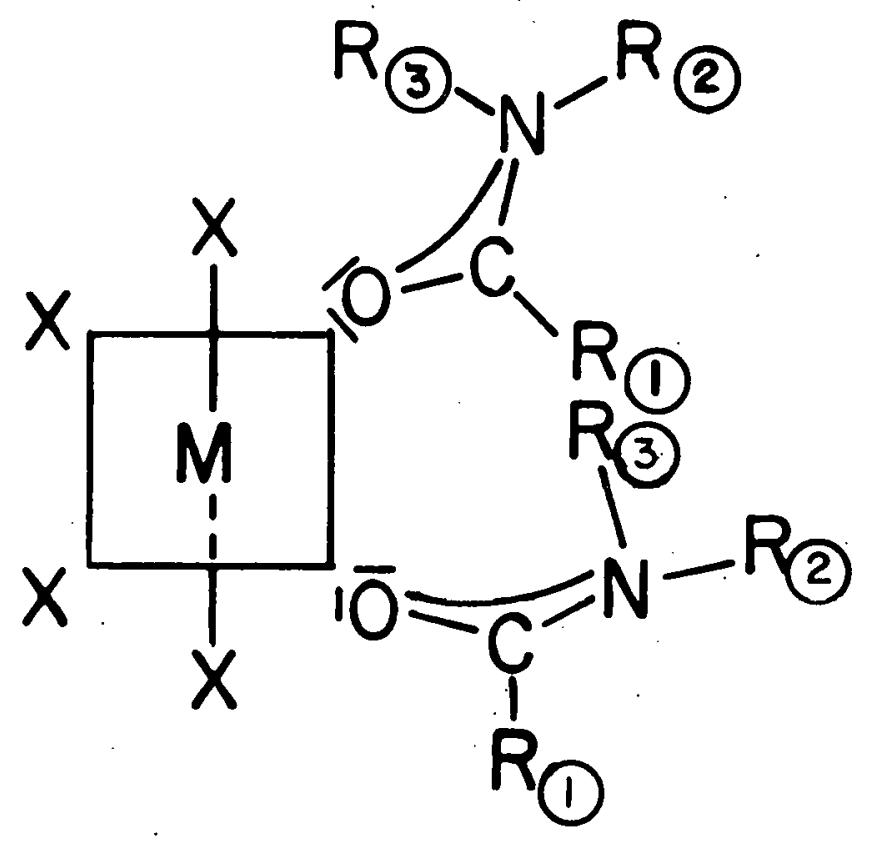

Figure 1. Interaction of neighboring amide groups in an octahedral complex. 
PRINCIPLES OF SOLVENT EXTRACTION

Detailed information on the theory and applications of solvent extraction are given by Morrison and Freiser (4), Irving and Williams (15), Irving, Rossetti and Williams (16), and in the Treatise on Analytical Chemistry (17). The following discussion is intended to provide sufficient information necessary for understanding the results of the present work.

Solvent extraction involves the partition of an uncharged species between two immiscible liquids. In a partition involving strong complexes of solvent and solute species, the following type of equilibrium is established,

$$
\mathrm{M}^{+\mathrm{R}}+\ell\left(\mathrm{NO}_{3}^{-}\right)+\mathrm{wH}_{2} \mathrm{O}+\mathrm{sS} \rightleftharpoons \mathrm{M}\left(\mathrm{NO}_{3}\right)_{\ell}\left(\mathrm{H}_{2} \mathrm{O}\right)_{\mathrm{W}} \mathrm{S}
$$

The equilibrium constant for this reaction is

$$
\mathrm{K}=\left[\mathrm{M}\left(\mathrm{NO}_{3}\right)_{\ell}\left(\mathrm{H}_{2} \mathrm{O}\right)_{\mathrm{W}^{\mathrm{S}}} \mathrm{S}\right] /\left[\mathrm{M}^{+\mathrm{R}}\right]\left[\mathrm{NO}_{3}^{-}\right]^{\ell}[\mathrm{S}]^{\mathrm{S}}\left[\mathrm{H}_{2} \mathrm{O}\right]^{\mathrm{W}}
$$

Assuming there are no further interactions in either phase, the distribution coefficient is

$$
D=\left[\mathrm{M}\left(\mathrm{NO}_{3}\right)_{\ell}\left(\mathrm{H}_{2} \mathrm{O}\right)_{\mathrm{W}} \mathrm{S} S /\left[\mathrm{M}^{+\mathrm{R}}\right]=\mathrm{K}\left[\mathrm{NO}_{3}^{-}\right]^{\ell}[\mathrm{S}]^{\mathrm{S}}\left[\mathrm{H}_{2} \mathrm{O}\right]^{\mathrm{W}}\right.
$$

Taking the log of both sides and assuming the concentration of water to be constant

$$
\log D=\log \mathrm{K}+\ell \log \left[\mathrm{NO}_{3}^{-}\right]+s \log [\mathrm{S}]
$$


Since $\mathrm{K}$ is constant, the expression can be written as.

$$
\log D=\ell \log \left[\mathrm{NO}_{3}^{-}\right]+s \log [S]+\text { constant }
$$

If the nitrate concentration is held constant and $D$ is measured with changes in solvent concentration, a plot of $\log D$ versus log [S] will produce a slope which is equal to the number of solvent molecules coordinated to the metal ion in the extracted species. In a similar manner, the solvent concentration can be held constant and the salt concentration varied, to determine the number of anions in the extracted species.

A term of practical interest when describing extraction is per cent extracted, \%E. This is related to the distribution coefficient by the following equation:

$$
\% E=100 D / D+\left(V_{W} / V_{0}\right)
$$

where $V_{W}$ and $V_{O}$ are the volumes of the aqueous and organic phases, respectively. Figure 2. graphically portrays the interconversion of $\mathrm{D}$ and $\% \mathrm{E}$. The total percentage of solute extracted after $n$ extractions with fresh solvent (in each extraction $V_{o}=V_{w}$ ) is given by the following equation:

$$
\% E=100-100 /(D+1)^{n}
$$

The stability of a metal coordination complex depends on 1). the "acidity" of the metal 1on, 2) the "basicity" of the coordinating ligand, 3) and factors related to the 


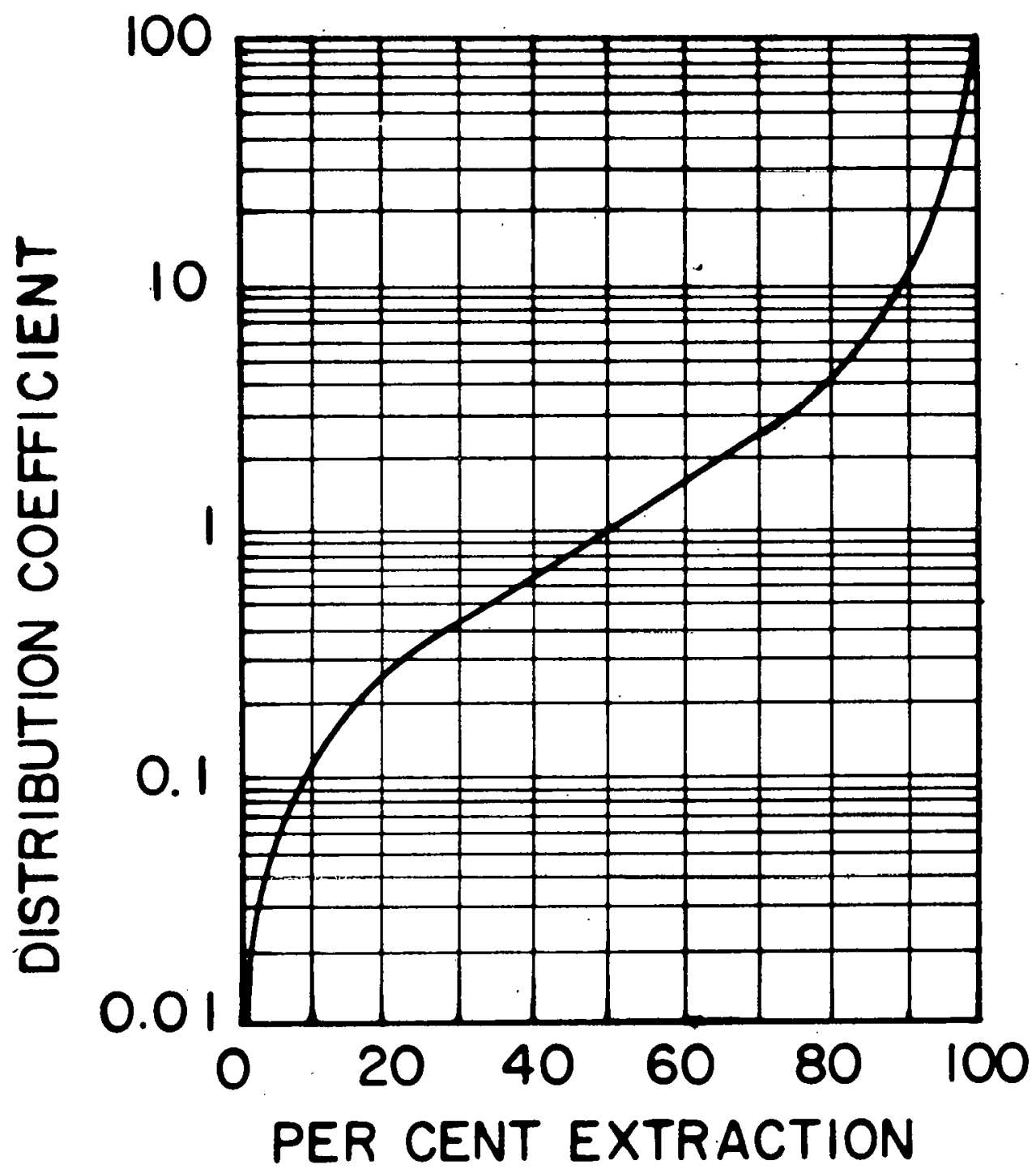

Figure 2. Relation of distribution coefficient to per cent extraction $\left(\mathrm{V}_{\mathrm{O}}=\mathrm{V}_{\mathrm{W}}\right)$. 
configuration of the complex. The acidity of the metal ion can be related to its charge and size. The higher and more concentrated the ionic charge on a metal ion the greater its acidity; therefore, small and highly charged cations form the most stable complexes. The basicity of the ligand can be related to its affinity for a proton, and its attraction to an electron deficient ion or molecule. Since metal ions are much larger than protons, the affinity of the ligand for a metal ion cannot be directly related to its proton affinity. Steric considerations are also important. However, in a series of closely related ligands, the ligands with the greatest proton affinity form the strongest complexes.

There are certain trends in the stability of metal complexes. One of these trends is the Irving-Williams series of stability (18). For a given ligand, the stability of complexes with dipositive metal ions follows the order:

$$
\mathrm{Ba}^{2+}<\mathrm{Sr}^{2+}<\mathrm{Ca}^{2+}<\mathrm{Mg}^{2+}<\mathrm{Mn}^{2+}<\mathrm{Fe}^{2+}<\mathrm{CO}^{2+}<\mathrm{Ni}^{2+}<\mathrm{Cu}^{2+}>\mathrm{Zn}^{2+}
$$

This order is due to the decrease in size across the series and to ligand f'ield ef'fects.

Another method of describing trends in complex formation is the soft-hard, acid-base theory (19). This theory classifies aclds and bases as being hard or soft and predicts that hard acids prefer to bind to hard bases and soft acids prefer to bind to soft bases. Hard acids or bases have high 
charges, small size and closed electron shells. Soft acids or bases have low charges and large size. Examples of some hard acids are the alkali and alkaline earth metals, $\mathrm{Cr}^{3+}$, $\mathrm{Co}^{3+}, \mathrm{Al}^{3+}, \mathrm{Fe}^{3+}, \mathrm{Th}^{4+}$ and $\mathrm{UO}_{2}{ }^{2+}$. Some soft acias are $\mathrm{Cu}^{+}$, $\mathrm{Au}^{+}, \mathrm{Cd}^{2+}, \mathrm{Hg}^{2+}, \mathrm{Pd}^{2+},{\mathrm{P} . t^{2+}}^{2}$ and $\mathrm{Pt}^{4+}$. Some hard bases are $\mathrm{NH}_{3}, \mathrm{H}_{2} \mathrm{O}, \mathrm{OH}^{-}, \mathrm{F}^{-}, \mathrm{Cl}^{-}, \mathrm{O}^{2-}, \mathrm{NO}_{3}^{-}$, and $\mathrm{ClO}_{4}^{-}$, and some soft bases are $\mathrm{H}^{-}, \mathrm{R}^{-}, \mathrm{CN}^{-}, \mathrm{CO}, \mathrm{SCN}^{-}, \mathrm{RS}^{-}$, and $\mathrm{I}^{-}$. Since there is no sharp dividing line between hard and soft, there are some borderline acids and bases. Some borderline acids are $\mathrm{Fe}^{2+}$, $\mathrm{Co}^{2+}, \mathrm{Ni}^{2+}, \mathrm{Cu}^{2+}, \mathrm{Zn}^{2+}, \mathrm{NO}^{+}$, and $\mathrm{SO}_{2}$. Some borderline bases are $\mathrm{C}_{6} \mathrm{H}_{5} \mathrm{NH}_{2}, \mathrm{C}_{5} \mathrm{H}_{5} \mathrm{~N}, \mathrm{~N}_{3}^{-}, \mathrm{N}_{2}, \mathrm{NO}_{2}^{-}, \mathrm{SO}_{3}{ }^{2}$, and $\mathrm{Br}^{-}$.

In addition to coordination compounds, there are a large number of uncharged compounds formed by the association of oppositely charged ions in pairs or clusters of higher order. A major fraction of the extractable species other than those that are chelates exist in the organic solvent as ion association aggregates. For two ions that associate according to the equation,

$$
\mathrm{A}^{+}+\mathrm{B}^{-} \rightleftharpoons\left(\mathrm{A}^{+}, \mathrm{B}^{-}\right)
$$

the equilibrium expression is

$$
K=\left[\left(A^{+}, B^{-}\right)\right] /\left[A^{+}\right]\left[B^{-}\right]
$$

Bjerrum related the value of $K$ to the dielectric constant of the solvent, to the temperature, and to the size of the ions involved $(20)$. 


$$
\begin{aligned}
& K=\frac{4 \pi N}{1000} \frac{e^{2}}{\varepsilon k T} Q(b) \\
& b=\frac{e^{2}}{a \varepsilon k T}
\end{aligned}
$$

where $N$ is Avogadro's number, $e$ is the unit of charge, $k$ is the Boltzman constant, $\varepsilon$ is the dielectric constant, $T$ is the absolute temperature, $Q(b)$ is a calculable function, and $a$ is an empirical parameter representing the distance between charge centers of the paired ions when in contact. From this equation it is evident that ion-association is best in solvents with low dielectric constants, and when the distance between the paired ions charge centers is small. Because of these factors the value of $K$ increases with decreasing anion size, and the presence of high concentrations of electrolyte in the solution increases $K$ because the dielectric constant of the aqueous phase is decreased by the electrolytes.

Ion-association compounds can be considered as polar molecules whose solublitty in organic solvents depends on their structural resemblance to these solvents. Oxygen containing organic liquids (oxonium solvents) work well as solvents for many metal salts, because the basic character of the oxygen atom enables the solvent to enter the coordination sphere of the metal which gives an fon association compound with a structural resemblance to the solvent. 
The ability of an oxonium solvent to enter into the coordination sphere of a metal ion depends on the basic1ty of the oxygen in the molecule, and on the steric availability of the electrons on the solvent.

The competition of water for the coordination sphere can be reduced by the use of high concentrations of salts and/or acids. High electrolyte concentration helps extraction in three ways: 1) by the mass action effect -- if the electrolyte has suitable coordinating anions, the high anion concentration makes the replacement of water by the anion easier, 2) by reducing the water activity, and 3) by lowering the dielectric constant. 


\section{EXPERIMENTAL}

\section{Apparatus}

A Cary 16 spectrophotometer was used to determine the absorbance of samples analyzed colorimetrically.

\section{Reagents}

The standard solution of zirconium was prepared from hafnium-free $\mathrm{ZrOCl}_{2} \cdot 8 \mathrm{H}_{2} \mathrm{O}$ prepared at the Ames Laboratory of the Atomic Energy Commission. All other solutions of metal ions were prepared from reagent grade metal nitrates. N,Ndiethyldodecanamide (DEDA), m.p. $3-4^{\circ} \mathrm{C}$, was purchased from Eastman Organic Chemicals, and $\mathrm{N}, \mathrm{N}$-dibutylformamide (DBFA), b.p. $120^{\circ} \mathrm{C}$ at $15 \mathrm{~mm}, \mathrm{n}_{D}^{20} 1.4429$, was purchased from Aldrich Chemical Company. Both amides were used without further purification.

The standard $0.05 \mathrm{M}$ EDTA solution was prepared from reagent grade disodium dihydrogen ethylenediaminetetraacetate dihydrate. The solution was standardized by titrating with zinc nitrate at $\mathrm{pH} 8$ to 10 with Eriochrome Black T indicator. Arsenazo I, 3-(2-arsonophenylazo)-4,5-dihydroxy-2,7naphthalene-disulfonic acid, was purchased from Eastman Organic Chemicals, and was purified by dropping a saturated aqueous solution of Arsenazo I into an equal volume of concentrated hydrochloric acid. The orange precipitate was 
filtered off and washed with acetonitrile. The product was dried at $110^{\circ} \mathrm{C}$ for $1-2$ hours and a 0.001 M aqueous solution was prepared.

\section{Preparation of N,N-Dihexylacetamide}

Equal molar quantities of acetic anhydride and di-nhexylamine were dissolved in ether and left to stand overnight. The solution was shaken with several portions of sodium bicarbonate solution to neutralize the acetic acid formed in the reaction. Then the organic layer was shaken with $3.0 \mathrm{M}$ hydrochloric actd to remove any amine remaining in the solution. The ether was removed from the product by fractional distillation, and the product was dried by standing over magnesium sulfate. The final product was purified by. vacuum distillation at $150^{\circ} \mathrm{C}$ at a pressure of $4 \mathrm{~mm}$ mercury.

The NMR and infrared spectra are shown in Figures 3 and 4. Proceeding downfield, the integration on the NMR spectra is $6,16,3$, and 4 , respectively. The triplet at 80.9 corresponds lu the methyl groupd at the end of the hexyl groups. The singlet at $\delta 1.9$ corresponds to the methyl group adjacent to the carbonyl group, and the triplet at $\delta 3.2$ corresponds to the methylene groups adjacent to the nitrogen. The strong band at $1650 \mathrm{~cm}^{-1}$ on the IR spectra corresponds to the carbonyl stretching vibrations for tertiary amides, and the strong band at $1450 \mathrm{~cm}^{-1}$ corresponds to $\mathrm{C}-\mathrm{N}$ stretching vibrations. 


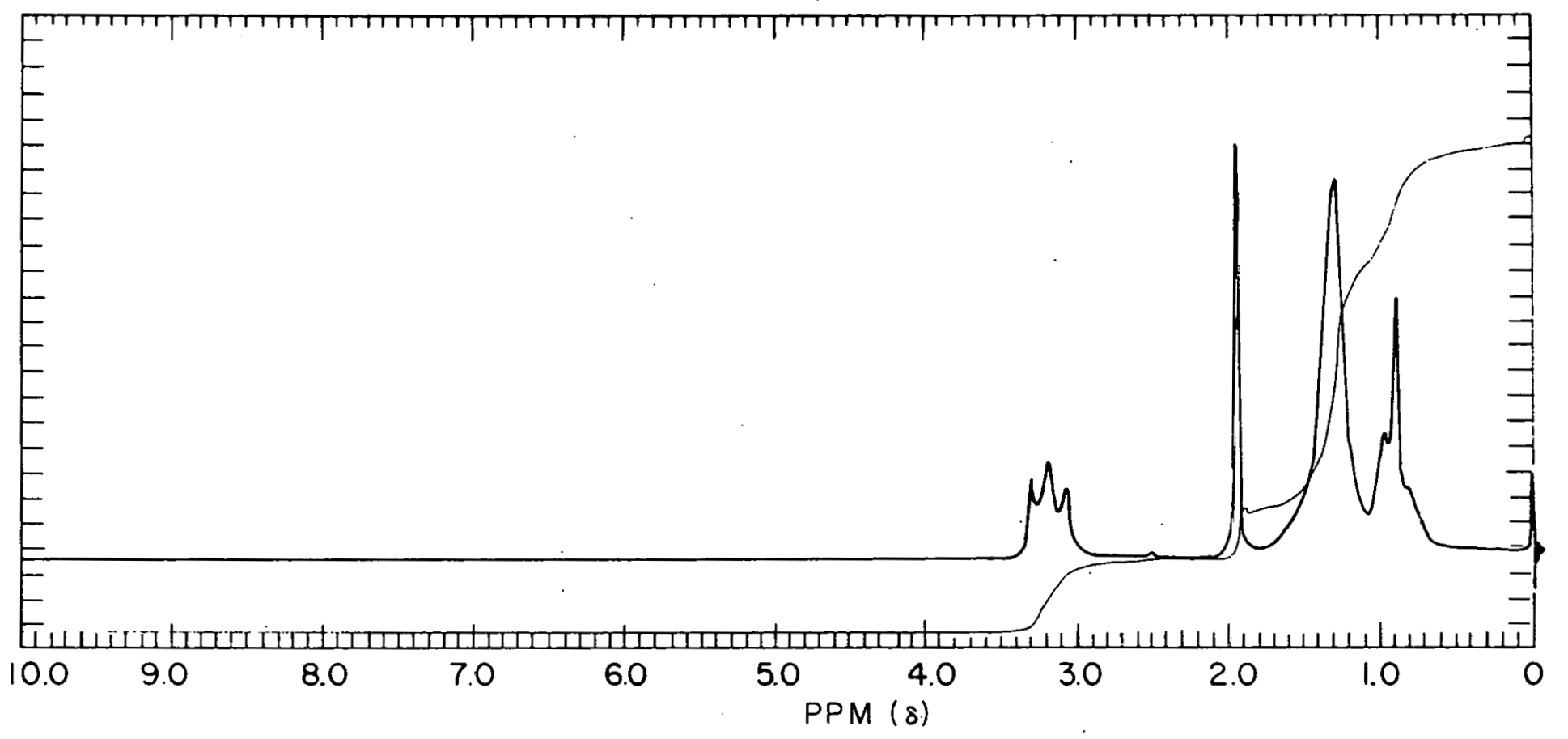

Figure 3. NMR spectra of $\mathrm{N}, \mathrm{N}$-dihexylacetamide. 


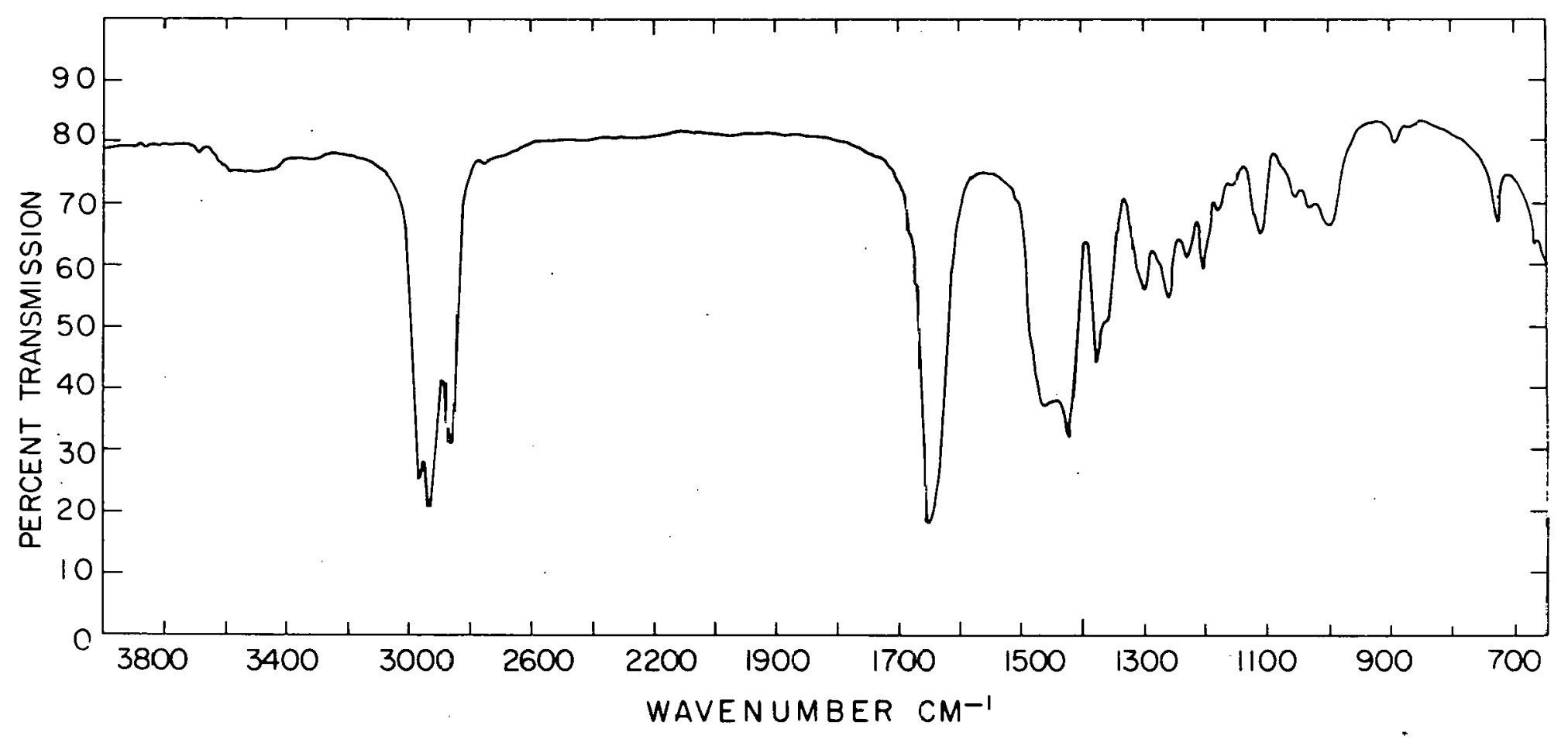

$\stackrel{\sqcup}{ }$

Figure 4. Infrared spectra of $\mathrm{N}, \mathrm{N}$-dihexylacetamide. 
Physical Properties of the N,N-Disubstituted Amides Used

$\begin{array}{ccccc}\text { Amide } & \begin{array}{c}\text { Molecular } \\ \text { Weight }\end{array} & \begin{array}{c}\text { Specific } \\ \text { Gravity }\end{array} & \begin{array}{c}\text { Melting } \\ \text { Point }\end{array} & \begin{array}{c}\text { Boiling } \\ \text { Point }\end{array} \\ \text { N,N-Dibutylformamide } & 157.26 & 0.88 & -- & 101-102^{\circ} \mathrm{C} / 5 \mathrm{~mm} \\ \text { N,N-Diethyldodecanamide } & 255.45 & 0.86 & 3-4^{\circ} \mathrm{C} & --- \\ \text { N,N-Dihexylacetamide } & 227.38 & 0.88 & -- & 150^{\circ} \mathrm{C} / 5 \mathrm{~mm}\end{array}$

Analytical Techniques

Uranium was determined colorimetrically with Arsenazo I (21). An aliquot containing 5-500 ug of uranium was adjusted to $\mathrm{pH} 2$ or 3 with ammonium hydroxide. To the sample was added $0.5 \mathrm{ml}$ of $0.05 \mathrm{M}$ EDTA to complex foreign metal ions, $4.0 \mathrm{ml}$ of $0.001 \mathrm{M}$ Arsenazo, $5 \mathrm{ml}$ of triethanolamine buffer (equal volumes of $1.0 \mathrm{M}$ triethanolamine and $0.05 \mathrm{M} \mathrm{HNO}_{3}$ ), and the solution was diluted to approximately $40 \mathrm{ml}$. The $\mathrm{pH}$ of the solution was adjusted to 7.5 with $\mathrm{HNO}_{3}$ or $\mathrm{NH}_{4} \mathrm{OH}$. The solution was then transferred to a $50 \mathrm{ml}$ volumetric flask and diluted to volume. The absorbance was measured in a $1 \mathrm{~cm}$ cell at $595 \mathrm{~nm}$.

All other metal ions were determined by titration with EDTA. Calcium was determined with Calmagite at $\mathrm{pH} 10$, and magnesium was determined with Erluchrome Black $\mathrm{T}$ at $\mathrm{pH} 10$. The other metal ions were determined with Xylenol Orange or Naphthyl Azoxine $S$ (NAS), as specified by Fritz, Abbink and Payne (22). 
Experimental Procedure

Extractions were performed on the metal ions $\mathrm{Al}^{3+}$, $\mathrm{Ca}^{2+}, \mathrm{Cd}^{2+}, \mathrm{Cu}^{2+}, \mathrm{Co}^{2+}, \mathrm{Fe}^{3+}, \mathrm{Hg}^{2+}, \mathrm{Mg}^{2+}, \mathrm{Ni}^{2+}, \mathrm{Pb}^{2+}, \mathrm{Th}^{4+}$, $\mathrm{UO}_{2}^{2+}, \mathrm{Zn}^{2+}$, and $\mathrm{ZrO}^{2+}$. One set of extractions was carried out by holding the amide concentrations constant, (DBFA, 2.0 M; DEDA, $1.0 \mathrm{M}$ and DHAA, 2.0 M) and at nitrate or perchlorate concentrations of $0.20 \mathrm{M}, 0.50 \mathrm{M}, 0.75 \mathrm{M}, 1.0 \mathrm{M}$ and $2.0 \mathrm{M}$, except for the extraction with DHAA, where the anion concentration of $0.20 \mathrm{M}$ was omitted. Another set of extrations were conducted by holding the nitrate or perchlorate concentrations at $1.0 \mathrm{M}$ and with amide concentrations as follows: $\mathrm{DBFA}-1.0 \mathrm{M}, 2.0 \mathrm{M}, 3.0 \mathrm{M}, 4.0 \mathrm{M}, 5.0 \mathrm{M}$; DEDA $0.25 \mathrm{M}, 0.50 \mathrm{M}, 1.0 \mathrm{M}, 2.0 \mathrm{M}, 3.0 \mathrm{M} ;$ DHAA - $0.5 \mathrm{M}, 1.0 \mathrm{M}$, $2.0 \mathrm{M}, 3.5 \mathrm{M}$.

To 60-ml separatory funnels were added exactly $5 \mathrm{ml}$ of $0.1 \mathrm{M}$ metal ion in $0.02 \mathrm{M} \mathrm{HNO}_{3}$, appropriate amounts of $4.0 \mathrm{M}$ sodium nitrate or sodium perchlorate and water to make the volume $10 \mathrm{ml}$, and $10 \mathrm{ml}$ of the appropriate amide in toluene. The mixture was placed on a Burrell Wrist-Action shaker and equilibrated for one hour. The lower aqueous phase was run off and analyzed for the amount of metal ion present after extraction. 


\section{RESULTS AND DISCUSSION}

Distribution coefficients for metal ions extracted from nitrate solution with DBFA, DEDA, and DHAA are given in Tables 1,2 and 3 , respectively.

The only ions extracted from nitrate solution by any of the amides were the actinides, zirconium, the small highly charged iron(III) ion, and the large mercury and lead lons. Uranium, thorium, zirconium and mercury were extracted to some extent by all of the amides studied, whereas iron was extracted only by $\mathrm{N}, \mathrm{N}$-dibutylformamide and $\mathrm{N}, \mathrm{N}-\mathrm{dihexyl-}$ acetamide, and lead was extracted only to a small extent by the formamide. The best extractant for the actinides appears to be DHAA, and for the other ions the formamide appears to be the superior extractant.

The data suggest the separation of uranium, thorium, and zirconium from many other metal ions and from each other. It appears that uranium can be separated from any of the metal ions studied regardless of the extraotant, however, DEDA appears to be the most selective extractant for uranium. The highest separation factors between thorium and the other ions is with DHAA at high amide and nitrate concentrations. The best separation of zirconium from the other ions appears to be with DBFA. As a comparison of the selectivity of the three amides towards uranium, thorium, and zirconium, one can 
$21 a$

THIS PAGE

WAS INTENTIONALLY

LEFT BLANK 
Table 1. Distribution coefficients for metal ions extracted from nitrate solution with N,N-dibutylformamide

$\begin{array}{llllll}0.20 \mathrm{M} \mathrm{NO}_{3}^{-} & 0.50 \mathrm{M} \mathrm{NO}_{3}^{-} & 0.75 \mathrm{M} \mathrm{NO}_{3}^{-} & 1.0 \mathrm{M} \mathrm{NO}_{3}^{-}\end{array}$ 2.0 M DBFA 2.0 M DBFA 2.0 M DBFA 2.0 M DBFA

\begin{tabular}{|c|c|c|c|c|}
\hline Al & 0.0 & 0.0 & 0.0 & 0.0 \\
\hline $\mathrm{Ca}$ & 0.0 & 0.0 & 0.0 & 0.0 \\
\hline $\mathrm{Cd}$ & 0.0 & 0.0 & 0.0 & 0.0 \\
\hline Co & 0.0 & 0.0 & 0.0 & 0.0 \\
\hline $\mathrm{Cu}$ & 0.0 & 0.0 & 0.0 & 0.0 \\
\hline $\mathrm{Fe}$ & 0.0 & 0.0 & 0.0 & 0.0 \\
\hline $\mathrm{Hg}_{\mathrm{g}}$ & 0.11 & 0.11 & 0.14 & 0.21 \\
\hline $\mathrm{Mg}$ & 0.0 & 0.0 & 0.0 & 0.0 \\
\hline $\mathrm{Ni}$ & 0.0 & 0.0 & 0.0 & 0.0 \\
\hline $\mathrm{Pb}$ & 0.0 & 0.0 & 0.0 & 0.0 \\
\hline Th & --- & 0.14 & 0.22 & 0.76 \\
\hline $\mathrm{U}$ & 2.4 & -- & -- & .24 .13 \\
\hline $\mathrm{Zn}$ & 0.0 & 0.0 & 0.0 & 0.0 \\
\hline $\mathrm{Zr}$ & 0.0 & 0.0 & 0.12 & 0.17 \\
\hline
\end{tabular}




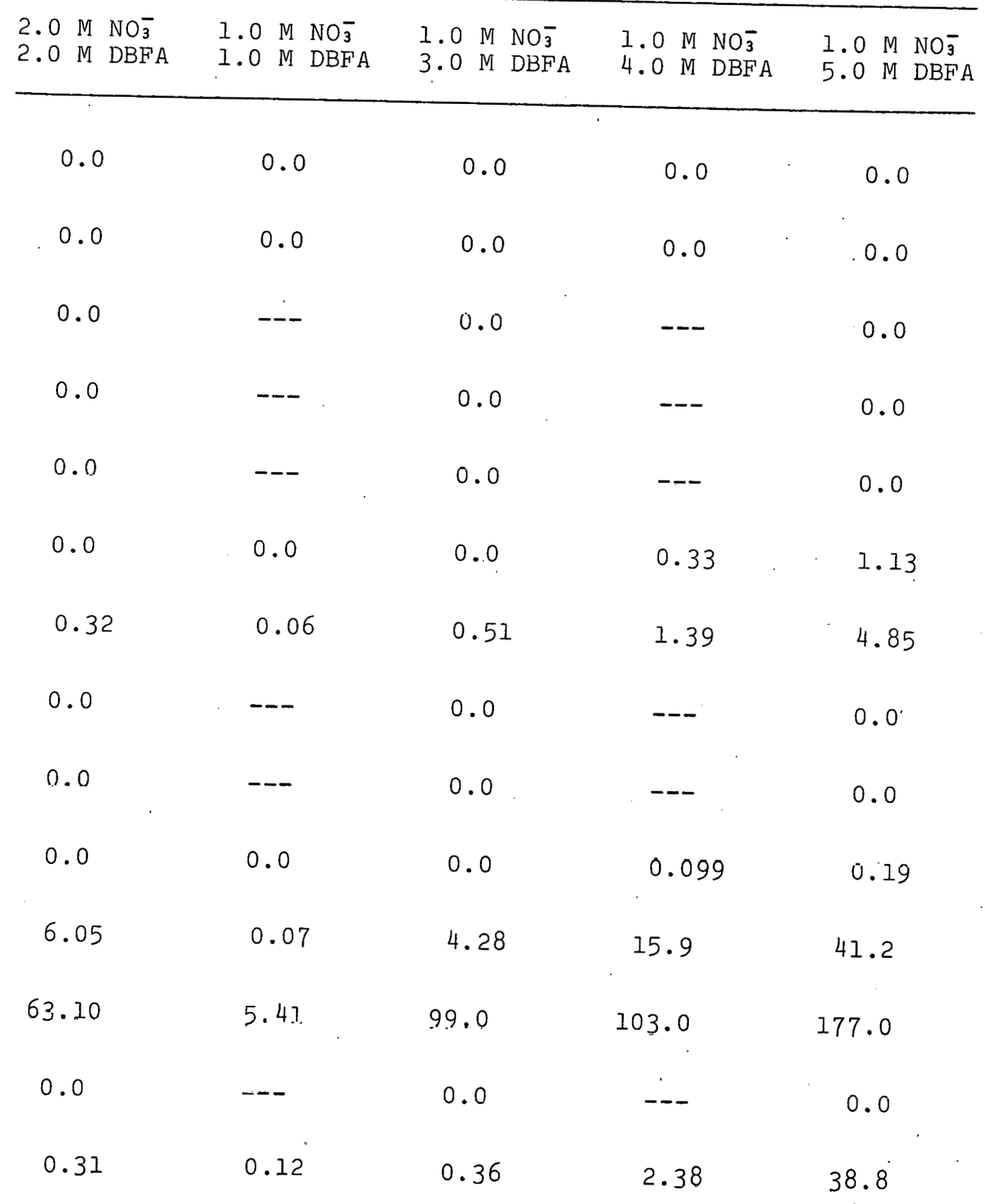


Table 2. Distribution coefficients for metal ions extracted from nitrate. solutions with N,N-dlethyldodecanamide

$\begin{array}{llllllll}0.20 \mathrm{M} \mathrm{NO}_{3}^{-} & 0.50 \mathrm{M} \mathrm{NO}_{3}^{-} & 0.75 \mathrm{M} \mathrm{NO}_{3}^{-} & 1.0 \mathrm{M} \mathrm{NO}_{3}^{-}\end{array}$ $1.0 \mathrm{M} \mathrm{DEDA}$ 1.0 M DEDA $1.0 \mathrm{M}$ DEDA $1.0 \mathrm{M} \mathrm{DEDA}$

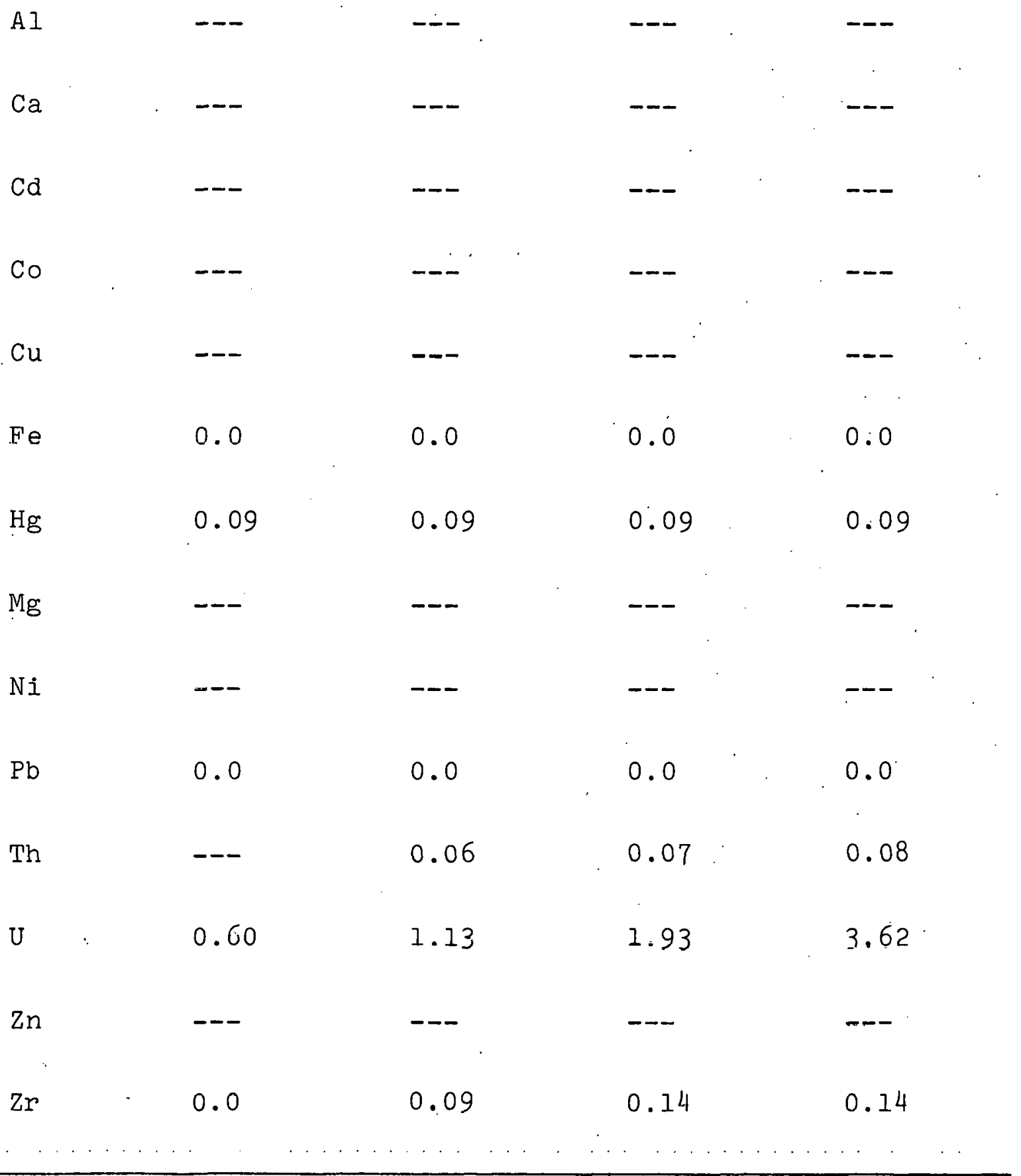


$22 a$

THIS PAGE

WAS INTENTIONALLY

LEFT BLANK 


\section{$2.0 \mathrm{M} \mathrm{NO}_{3}^{-} \quad 1.0 \mathrm{M} \mathrm{NO}_{3}^{-} \quad 1.0 \mathrm{M} \mathrm{NO}_{3}^{-} \quad 1.0 \mathrm{M} \mathrm{NO}_{3}^{-} \quad 1.0 \mathrm{M} \mathrm{NO}_{3}^{-}$}

$1.0 \mathrm{M} \mathrm{DEDA} \quad 0.25 \mathrm{M}$ DEDA. $0.5 \mathrm{M}$ DEDA $2.0 \mathrm{M}$ DEDA $3.0 \mathrm{M}$ DEDA

\begin{tabular}{|c|c|c|c|c|}
\hline-- & -- & --- & --- & 0.0 \\
\hline--- & --- & -- & --- & 0.0 \\
\hline-- & -- & --- & -- & 0.0 \\
\hline-- & -- & --- & - & 0.0 \\
\hline-- & -- & -- & -- & 0.0 \\
\hline 0.0 & 0.0 & 0.0 & 0.0 & 0.0 \\
\hline 0.09 & 0.09 & 0.09 & 0.09 & 0.25 \\
\hline--- & --- & -- & -- & 0.0 \\
\hline--- & --- & --- & -- & 0.0 \\
\hline 0.0 & 0.0 & 0.0 & 0.0 & 0.0 \\
\hline 0.15 & 0.07 & 0.08 & 0.17 & 0.66 \\
\hline 13.5 & 0.53 & 0.80 & 10.0 & 27.1 \\
\hline$-\cdots$ & --- & --- & --- & 0.0 \\
\hline 0.18 & 0.95 & 0.05 & 0.08 & 0.08 \\
\hline
\end{tabular}


Table 3. Iistribution coefficients for metal ions extracted from nitrate solution with N,N-dihexylacetamide.

$0.50 \mathrm{N.} \mathrm{NO}_{3}^{-} 0.75 \mathrm{M} \mathrm{NO}_{3}^{-}=.0 \mathrm{M} \mathrm{NO}_{3}^{-} 2.0 \mathrm{M} \mathrm{NO}_{3}^{-} \quad 1.0 \mathrm{M} \mathrm{NO}_{3}^{-} \quad 1.0 \mathrm{M} \mathrm{NO}_{3}^{-} \quad 1.0 \mathrm{M} \mathrm{NO}^{-}$ 2.0 M DHAA 2.0 M DHAF 2.0 M DHAA 2.0 M DHAA 0..5 M DHAA 1..0 M DHAA 3.5 IM DHAA

\begin{tabular}{lccccccc}
\hline $\mathrm{AI}$ & 0.0 & 0.0 & 0.0 & 0.0 & 0.0 & 0.0 & 0.0 \\
$\mathrm{ca}$ & 0.0 & 0.0 & 0.0 & 0.0 & 0.0 & 0.0 & 0.0 \\
$\mathrm{Cd}$ & 0.0 & 0.0 & 0.0 & 0.0 & 0.0 & 0.0 & 0.0 \\
$\mathrm{zo}$ & 0.0 & 0.0 & 0.0 & 0.0 & 0.0 & 0.0 & 0.0 \\
$\mathrm{Cu}$ & 0.0 & 0.0 & 0.0 & 0.0 & 0.0 & 0.0 & 0.0 \\
$\mathrm{Fe}$ & 0.0 & 0.02 & 0.03 & 0.05 & 0.0 & 0.0 & 0.22 \\
$\mathrm{Hg}$ & 0.10 & 0.13 & 0.20 & 0.31 & 0.01 & 0.04 & 1.12 \\
$\mathrm{Mg}$ & 0.0 & 0.0 & 0.0 & 0.0 & 0.0 & 0.0 & 0.0 \\
$\mathrm{Ni}$ & 0.0 & 0.0 & 0.0 & 0.0 & 0.0 & 0.0 & 0.0 \\
$\mathrm{~Pb}$ & 0.0 & 0.0 & 0.0 & 0.0 & 0.0 & 0.0 & 0.0 \\
$\mathrm{Th}$ & 0.36 & 0.70 & 2.48 & 17.8 & 0.06 & 0.33 & 26.5 \\
$\mathrm{U}$ & 24.5 & 63.9 & 105.0 & 624.0 & 4.84 & 25.3 & 249.0 \\
$\mathrm{Zn}$ & 0.0 & 0.0 & 0.0 & 0.0 & 0.0 & 0.0 & 0.0 \\
$\mathrm{Zr}$ & 0.03 & 0.01 & 0.04 & 0.04 & 0.04 & 0.02 & 0.09 \\
$\ldots \ldots$
\end{tabular}


compare the separation factors between the three metal ions when extracted from $1.0 \mathrm{M}$ nitrate solution with $3.0 \mathrm{M} \mathrm{DBFA}$, 3.0 M DEDA and 3.5 M DHAA. The separation factors between uranium and thorium for DBFA, DEDA, and DHAA are 23.1, 41.3, and 9.4 , respectively. Similarly, the separation factors between thorium and zirconium are 11.9, 7.95, and 297. DBFA is the only extractant which shows large separation factors between zirconium and iron, mercury and lead.

The mechanism of extraction of the metal ions extracted from nitrate solution might help explain the effect of the structure of amides on their extracting power and selectivity.

Figures 5 through 10 show log D versus log nitrate concentration and $\log D$ versus log amide concentration plots for DBFA, DEDA, and DHAA. The plots for the extraction of uranium suggest that the extracted species contains two amides for each uranium extracted. Plots for mercury suggest that there are two amide groups extracted with each mercury ion. For the extraction of thorium there appear to be three amides for each thorium ion extracted when the solvent is DHAA or DEDA and four amides for each thorium ion extracted when the solvent is DBFA. Because of the high concentrations of electrolyte in the aqueous phase, the aqueous phase is $f a r$ from ided, and the 3 lopes of the log $D$ versus $\log \left[\mathrm{NO}_{3}^{-}\right]$are possibly different than if activity was plotted instead of concentration. Assuming this to be true, the extracted 


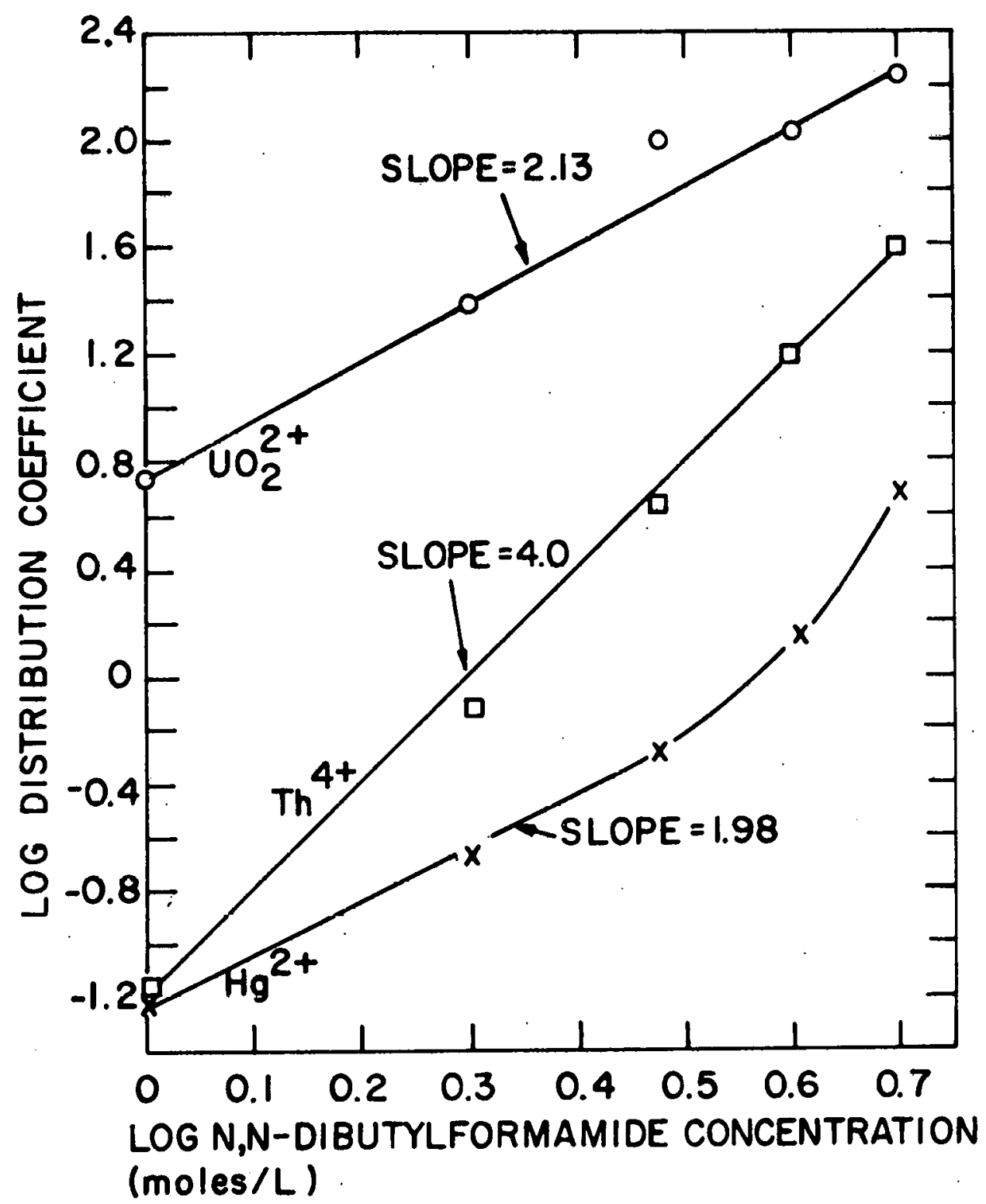

Figure 5. Log distribution coefficient versus log $\mathrm{N}$, N-dibutylformamide concentration for extraction from nitrate solution. 


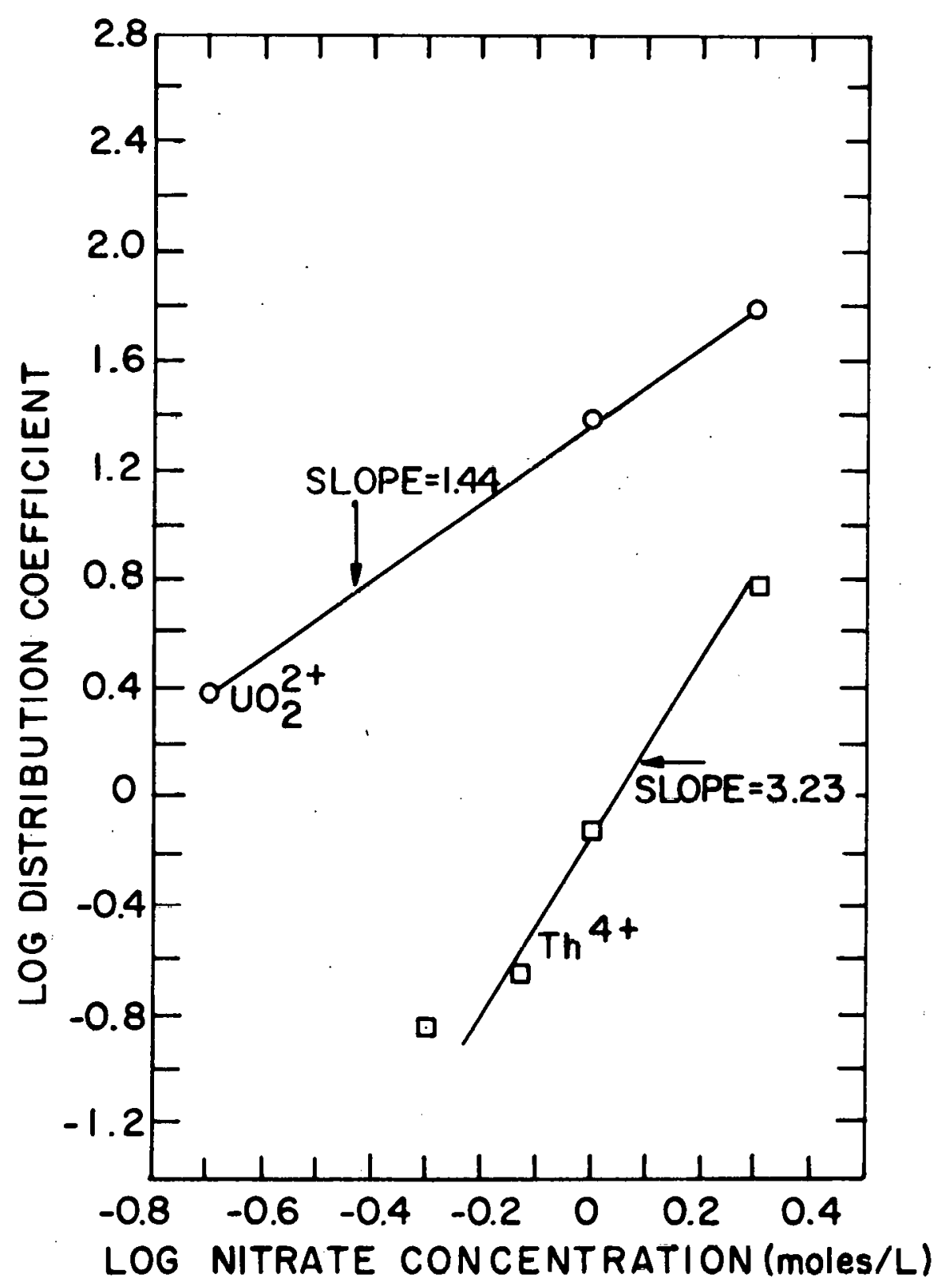

Figure 6. Log distribution coefficient versus log nitrate concentration for extraction with $\mathrm{N}, \mathrm{N}-$ dibutylformamide. 


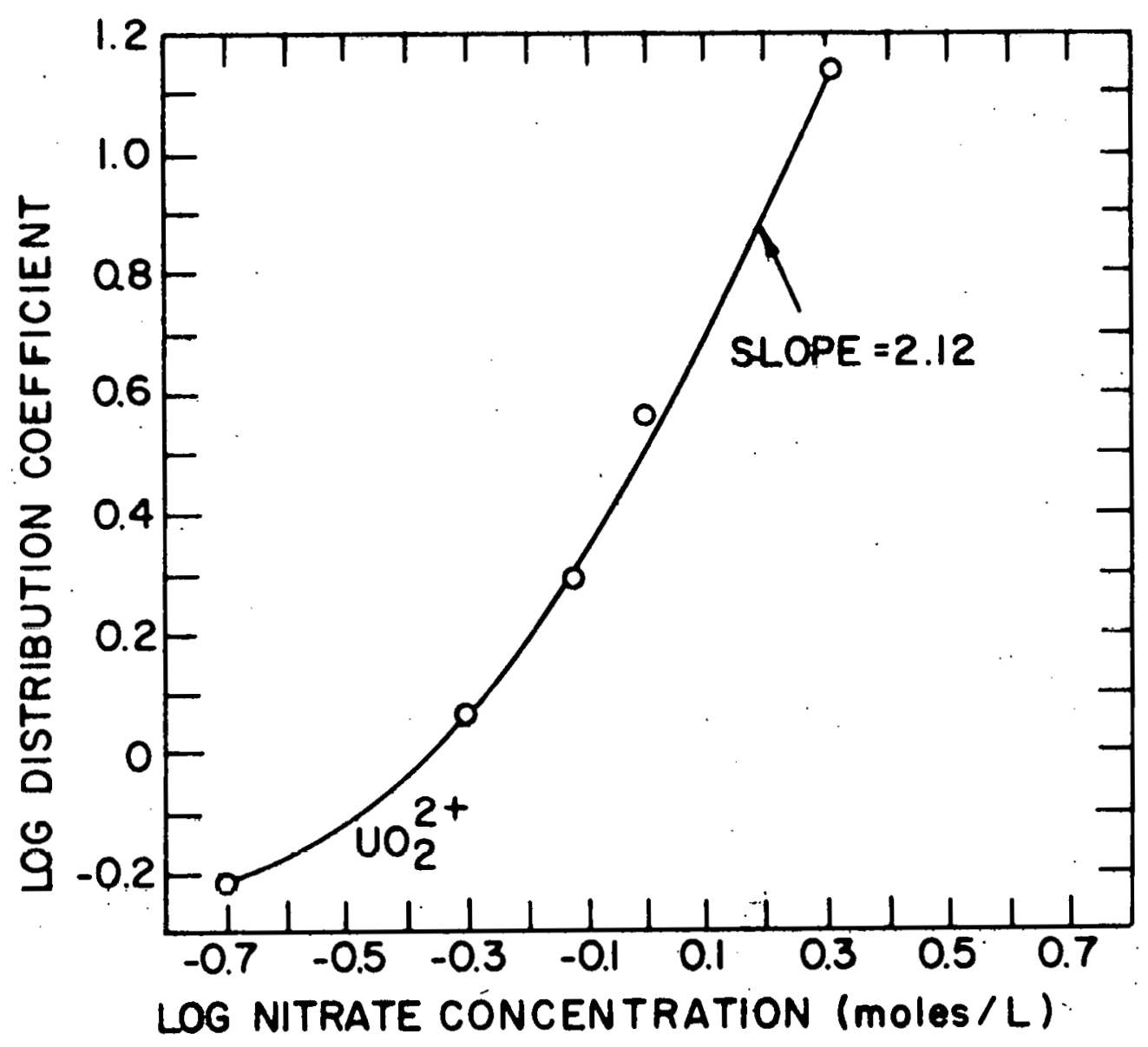

Figure 7. Log distribution coefficient versus log nitrate concentration for extraction with $\mathrm{N}, \mathrm{N}-$ diethyldodecanamide. 


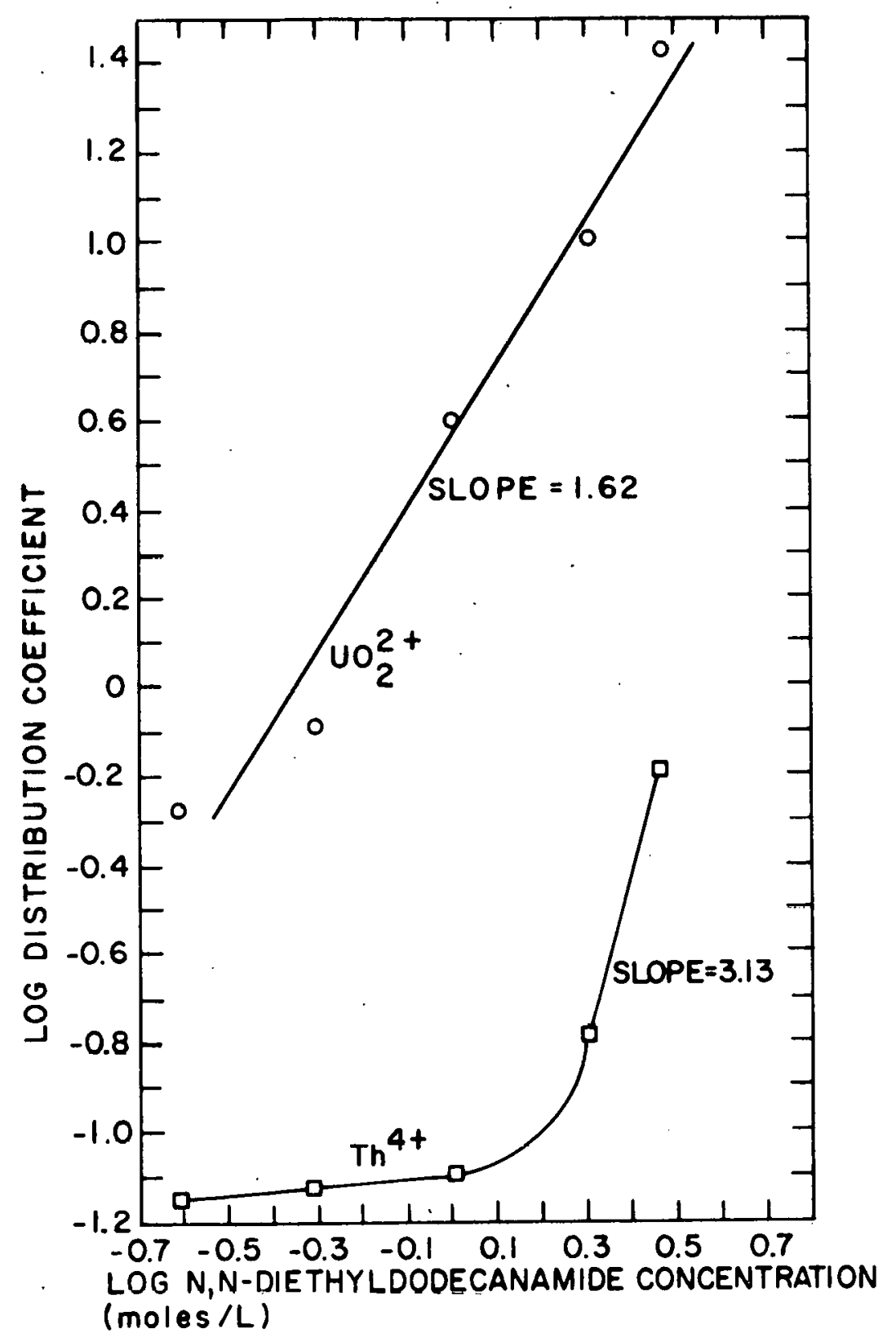

Figure 8. Log distribution coefficient versus log $\mathrm{N}, \mathrm{N}$-diethyldodecanamide concentration for extraction from nitrate solution. 


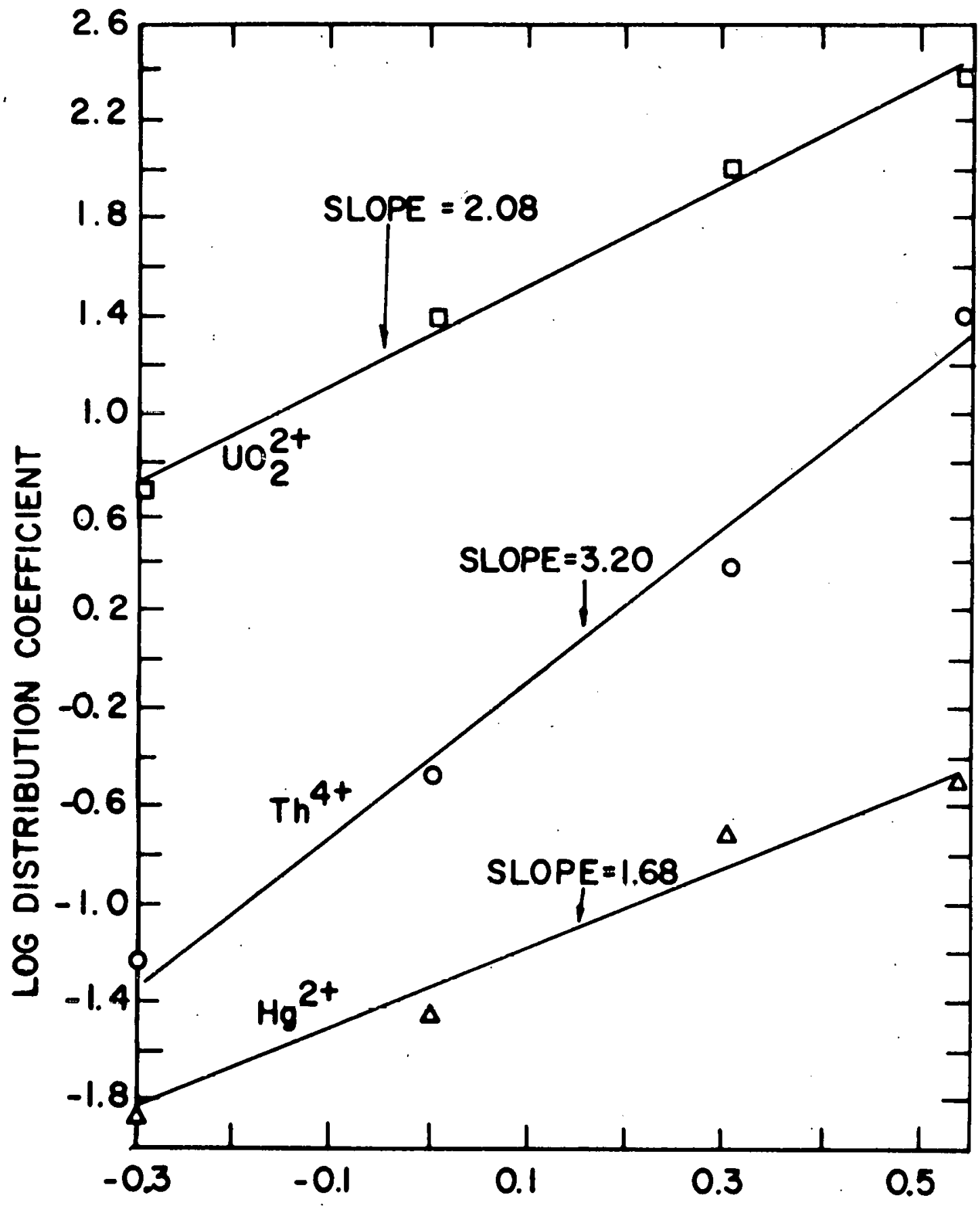

LOG N,N-DIHEXYLACETAMIDE CONCENTRATION (moles/L)

Figure 9. Log distribution coefficient versus $\log N, N-$ dihexylacetamide concentration for extraction from nitrate solution. 


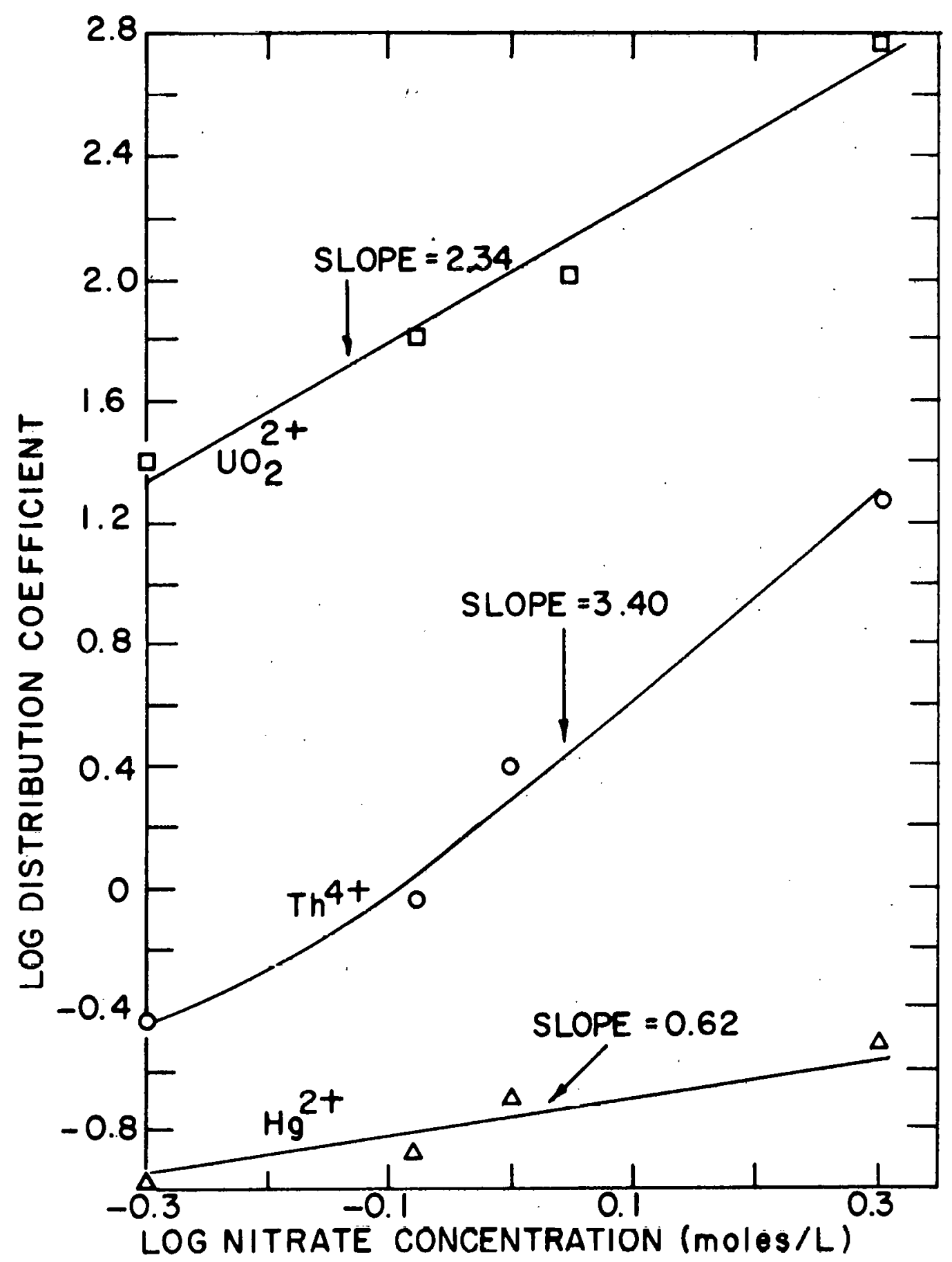

Figure 10. Log distribution coefficient versus log nitrate concentration for extraction with $\mathrm{N}, \mathrm{N}-$ dihexylacetamide. 
species are predicted to be $\mathrm{UO}_{2}$ (amide) $)_{2}\left(\mathrm{NO}_{3}\right)_{2}\left(\mathrm{H}_{2} \mathrm{O}\right)_{2}$, $\mathrm{Hg}(\text { amide })_{2}\left(\mathrm{NO}_{3}\right)_{2}\left(\mathrm{H}_{2} \mathrm{O}\right)_{2}$ and $\mathrm{Th}(\text { amide })_{3}$ or ${ }_{4}\left(\mathrm{NO}_{3}\right)_{4}\left(\mathrm{H}_{2} \mathrm{O}\right)_{1}$ or 0. As mentioned earlier, the lower carbonyl stretching frequency for amides than ketones can be attributed to resonance<smiles>[R]C(=O)N([R])[R]</smiles>

If this is the case, amides with electron-releasing groups on the $\alpha$-carbon and electron-withdrawing groups on the amine constituent should increase the availability of electrons on the oxygen atom for bonding. This factor along with steric factors should be the determining factors for the extracting power of various amides. DHAA is a better extractant for the actinides than DBFA, possibly because the methyl group on the carbon of the DHAA is a better electron donor than the hydrogen on DBFA. Also, since it was previously suggested that the acid substituents of the amides have a greater effect on their extracting power than the amine substituents. The larger hexyl groups on the DHAA would not hlave ds greal of an effect decreasing the extracting power of the amide as the more electron-releasing methyl group on the $\alpha$-carbon has increasing the extracting power.

The most likely reason that the DEDA is the poorest extractant of the three amides studied is simply because the large dodecyl group makes it sterically difficult for the amide to coordinate to the metal ion. 
The fact that the extracted uranium species contains two amide molecules and the extracted thorium species contains more than two amide molecules might explain why the best separation factor between thorium and uranium is obtained with DEDA. Since the thorium species contains more amide groups than the uranium species, there is more crowding around the coordination sphere of thorium, and the large alkyl group on DEDA would cause more crowding than the other two amides. Therefore, the highest separation factor is with DEDA.

Since no conclusions on the mechanism of extraction of zirconium have been made, it is difficult to predict why the zirconium is extracted much better by the formamide than the other two amides.

The results of the extractions from perchlorate solution with DBFA and DEDA were much different than the extraction from nitrate solution. The distribution coefficients are shown in Tables 4 and 5 . These large differences in the two systems can be attributed to the different roles that the nitrate and perchlorate ions play in the extraction mechanism. The nitrate ion is a coordinating ligand and forms coordination complexes with the metal ions that are extracted from nitrate solutiori. The nitrate ion is competing for the coordination sltes with the amide and water, and consequently the species extracted is a coordination complex. The perchlorate ion is a very poor coordinating ligand, and its spherical charge 
THIS PAGE

\section{WAS INTENTIONALLY LEFT BLANK}


Table 4. Distribution coefficients for metal ions extracted from perchlorate solution with N,N-dibutylformamide

\begin{tabular}{|c|c|c|c|c|}
\hline & $\begin{array}{l}0.20 \mathrm{M} \mathrm{ClO}_{4}^{-} \\
2.0 \mathrm{M} \mathrm{DBFA}\end{array}$ & $\begin{array}{l}0.50 \mathrm{M} \mathrm{ClO}^{-} \\
2.0 \mathrm{M} \mathrm{DBFA}\end{array}$ & $\begin{array}{l}0.75 \mathrm{M} \mathrm{ClO}_{4}^{-} \\
2.0 \mathrm{M} \mathrm{DBFA}\end{array}$ & $\begin{array}{l}1.0 \mathrm{M} \mathrm{ClO} \\
2.0 \mathrm{M} \mathrm{DBFA}\end{array}$ \\
\hline Al & 0.21 & 0.20 & 0.48 & 0.93 . \\
\hline $\mathrm{Ca}$ & 0.07 & 0.11 & 0.19 & 0.29 \\
\hline $\mathrm{Cd}$ & 0.10 & 0.19 & 0.35 & 0.56 \\
\hline Co & 0.01 & 0.17 & 0.28 & 0.47 \\
\hline $\mathrm{Cu}$ & 0.06 & 0.24. & 0.46 & 0.77 \\
\hline $\mathrm{Fe}$ & 1.64 & 7.78 & 19.5 & 19.5 \\
\hline $\mathrm{Hg}$ & 0.27 & 0.66 & 1.89 & 2.21 \\
\hline $\mathrm{Mg}$ & 0.0 & 0.03 & 0.16 & 0.25 \\
\hline $\mathrm{Ni}$ & 0.05 & 0.27 & 0.55 & 0.90 \\
\hline $\mathrm{Pb}$ & 0.17 & 0.66 & 1.19 & $1.98^{\circ}$ \\
\hline Th & 4.78 & 39.4 & 79.9 & 94.4 \\
\hline $\mathrm{U}$ & 2.85 & 15.9 & 23.2 & 79.0 \\
\hline $\mathrm{Zn}$ & 0.01 & 0.08 & 0.21 & 0.37 \\
\hline $\mathrm{Zr}$ & 10.4 & $\infty$ & $\infty$ & $\infty$ \\
\hline & $\ldots \ldots$ & . & $\ldots$ & \\
\hline
\end{tabular}




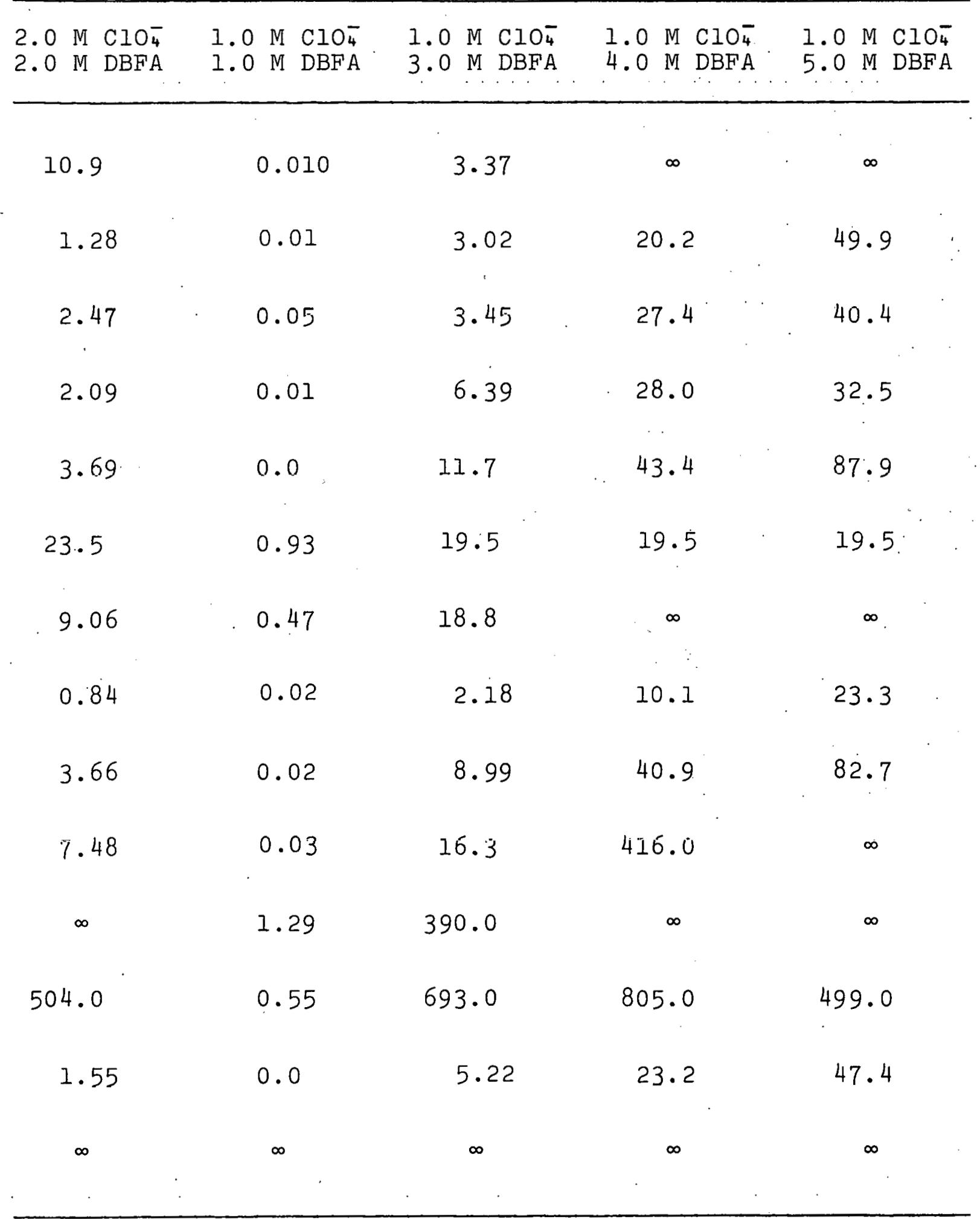


$34 a$

THIS PAGE

WAS INTENTIONALLY

LEFT BLANK 
Table 5. Distribution coefficients for metal ions extracted from perchlorate solution with N,N-diethyldodecanamide

\begin{tabular}{|c|c|c|c|c|c|}
\hline & $\begin{array}{l}0.20 \mathrm{M} \mathrm{ClO}_{4}^{-} \\
1.0 \mathrm{M} \mathrm{DEDA}\end{array}$ & $\begin{array}{l}0.50 \mathrm{M} \mathrm{ClO}_{4}^{-} \\
2.0 \mathrm{M} \mathrm{DEDA}\end{array}$ & $\begin{array}{l}0.75 \mathrm{M} \mathrm{ClO}^{-} \\
1.0 \mathrm{M} \mathrm{DEDA}\end{array}$ & $\begin{array}{l}1.0 \\
2.0\end{array}$ & $\begin{array}{l}\mathrm{M} \mathrm{ClO}_{4}^{-} \\
\mathrm{M} \mathrm{DEDA}\end{array}$ \\
\hline Al & 0.0 & 0.0 & 0.0 & & 0.0 \\
\hline $\mathrm{Ca}$ & 0.0 & 0.0 & 0.0 & & 0.0 \\
\hline $\mathrm{Cd}$ & 0.0 & 0.0 & 0.0 & & 0.0 \\
\hline $\mathrm{Co}$ & 0.0 & 0.0 & 0.0 & & 0.0 \\
\hline $\mathrm{Cu}$ & 0.0 & 0.0 & 0.0 & & 0.0 \\
\hline $\mathrm{Fe}$ & 0.0 & 0.0 & 0.0 & & 0.0 \\
\hline $\mathrm{Hg}$ & 0.06 & 0.06 & 0.06 & & 0.06 \\
\hline $\mathrm{Mg}$ & 0.0 & $0: 0$ & 0.0 & & 0.0 \\
\hline $\mathrm{N1}$ & 0.0 & 0.0 & 0.0 & & 0.0 \\
\hline $\mathrm{Pb}$ & 0.0 & 0.0 & 0.0 & & 0.0 \\
\hline Th & 0.0 & 0.0 & 0.0 & & 0.0 \\
\hline $\mathrm{U}$ & 0.35 & 0.19 & 0.15 & & 0.26 \\
\hline $\mathrm{Zn}$ & 0.0 & 0.0 & 0.0 & & 0.0 \\
\hline $\mathrm{Zr}$ & 0.0 & 0.0 & 0.0 & & 0.0 \\
\hline
\end{tabular}


$2.0 \mathrm{M} \mathrm{ClO}_{4}^{-} \quad 1.0 \mathrm{M} \mathrm{ClO}_{4}^{-} \quad 1.0 \mathrm{M} \mathrm{ClO}_{4}^{-} \quad 1.0 \mathrm{M} \mathrm{ClO}_{4}^{-} \quad 1.0 \mathrm{M} \mathrm{ClO}_{4}^{-}$ $1.0 \mathrm{M}$ DEDA $0.25 \mathrm{M}$ DEDA $0.50 \mathrm{M}$ DEDA $2.0 \mathrm{M}$ DEDA $3.0 \mathrm{M}$ DEDA

\begin{tabular}{|c|c|c|c|c|}
\hline 0.0 & 0.0 & 0.0 & 0.04 & 0.20 \\
\hline 0.0 & 0.0 & 0.0 & 0.0 & 0.70 \\
\hline 0.0 & 0.0 & 0.0 & 0.0 & 0.17 \\
\hline 0.0 & 0.0 & 0.0 & 0.0 & 0.11 \\
\hline 0.0 & 0.0 & 0.0 & 0.0 & 0,17 \\
\hline 0.0 & 0.0 & 0.0 & 0.0 & ppt. \\
\hline 0.07 & 0.03 & 0.03 & 0.10 & 0.99 \\
\hline 0.0 & 0.0 & 0.0 & 0.0 & 0.06 \\
\hline 0.0 & 0.0 & 0.0 & 0.0 & 0.08 \\
\hline 0.0 & u.u & 0.0 & 0.0 & 0.43 \\
\hline 0.0 & 0.0 & 0.0 & 0.08 & 3.21 \\
\hline 1.29 & 0.08 & -- & 20.8 & 332.0 \\
\hline 0.0 & 0.0 & 0.0 & 0.0 & 0.09 \\
\hline 0.04 & 0.0 & 0.0 & 0.0 & 0.67 \\
\hline
\end{tabular}


distribution makes it an excellent ion for formation of 1onassociation complexes. The perchlorate ion reduces the activity of water and the dielectric constant of the solution greatly, therefore, the amides readily coordinate to all of the sites in the coordination sphere and the species extracted is an ion-association complex.

The $\log D$ versus $\log$ perchlorate concentration and $\log D$ versus log amide concentration plots for the DBFA systems are shown in Figures 11 through 17 . From these figures it is predicted that in all cases except for that of $\mathrm{Cu}$ (II) the extracted species are $\left[\mathrm{M}(\operatorname{amide})_{6}^{\mathrm{n}^{+}}, \mathrm{nClO}_{4}^{-}\right]$. For $\mathrm{Cu}(\mathrm{II})$ the extracted species appears to be $\left[\mathrm{Cu}(\text { amide })_{2}\left(\mathrm{H}_{2} \mathrm{O} .\right)_{4}^{2+}, 2 \mathrm{ClO}_{4}^{-}\right]$. This is probably due to the fact that two of the water molecules coordinated around $\mathrm{Cu}$ (II) are farther from the metal atom than the other four and are more easily displaced. After these two water molecules have been displaced it becomes more difficult to replace the remaining water molecules.

It is very surprising that at high DEDA and perchlorate concentrations all of the metal ions are extracted to some extent, and with DBFA, all of the metal ions are extracted appreciably. It would be expected that there would be such a large amount of steric hinderance from six large amide groups courdinated around the metal ion that only the larger ions would be extracted. Although many ions which would not be expected to be extracted were extracted, the extent to which 


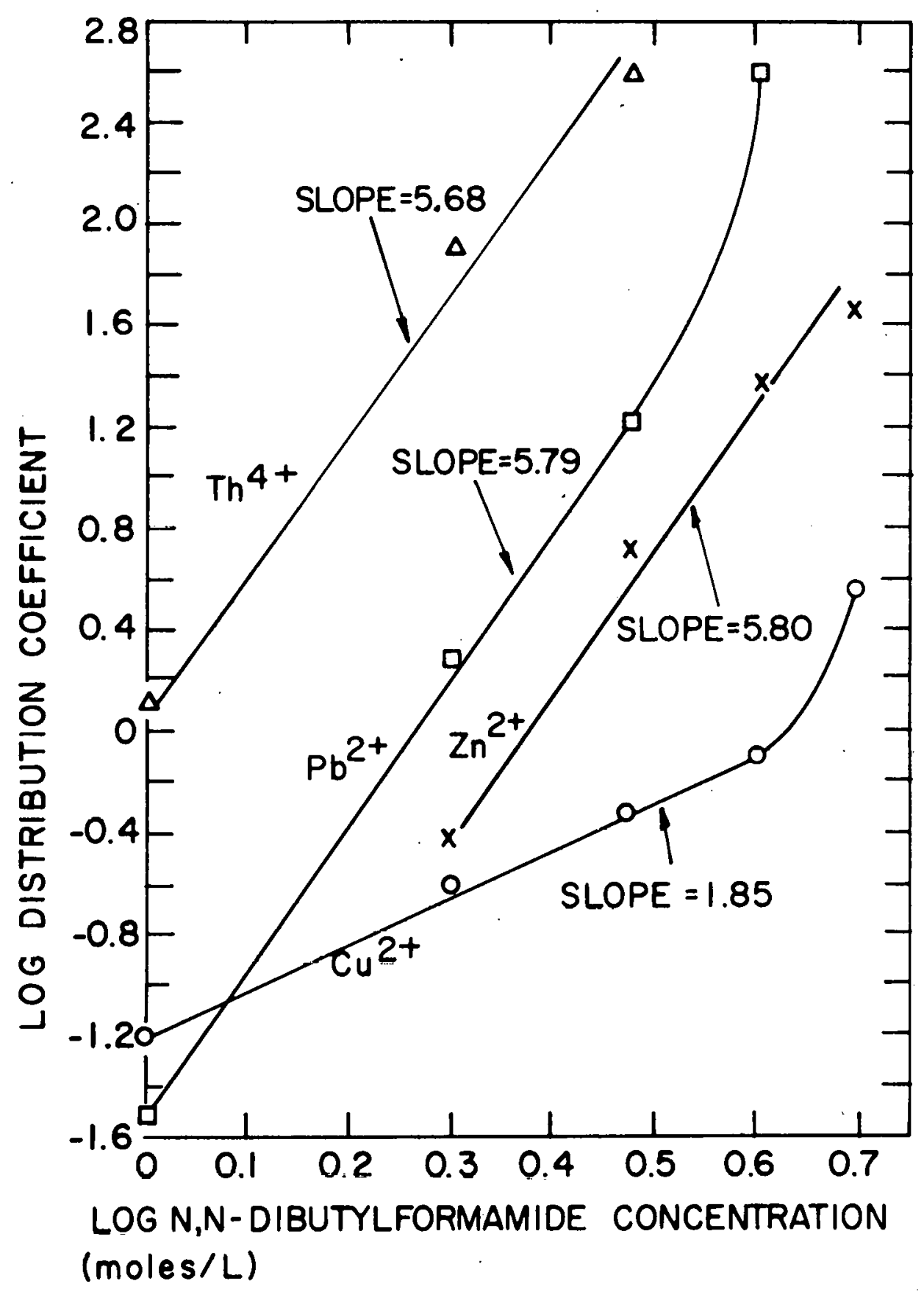

Figure 11. Log distribution coefficient versus log $\mathrm{N}, \mathrm{N}$-dibutylformamide concentration for extraction from perchlorate solution. 


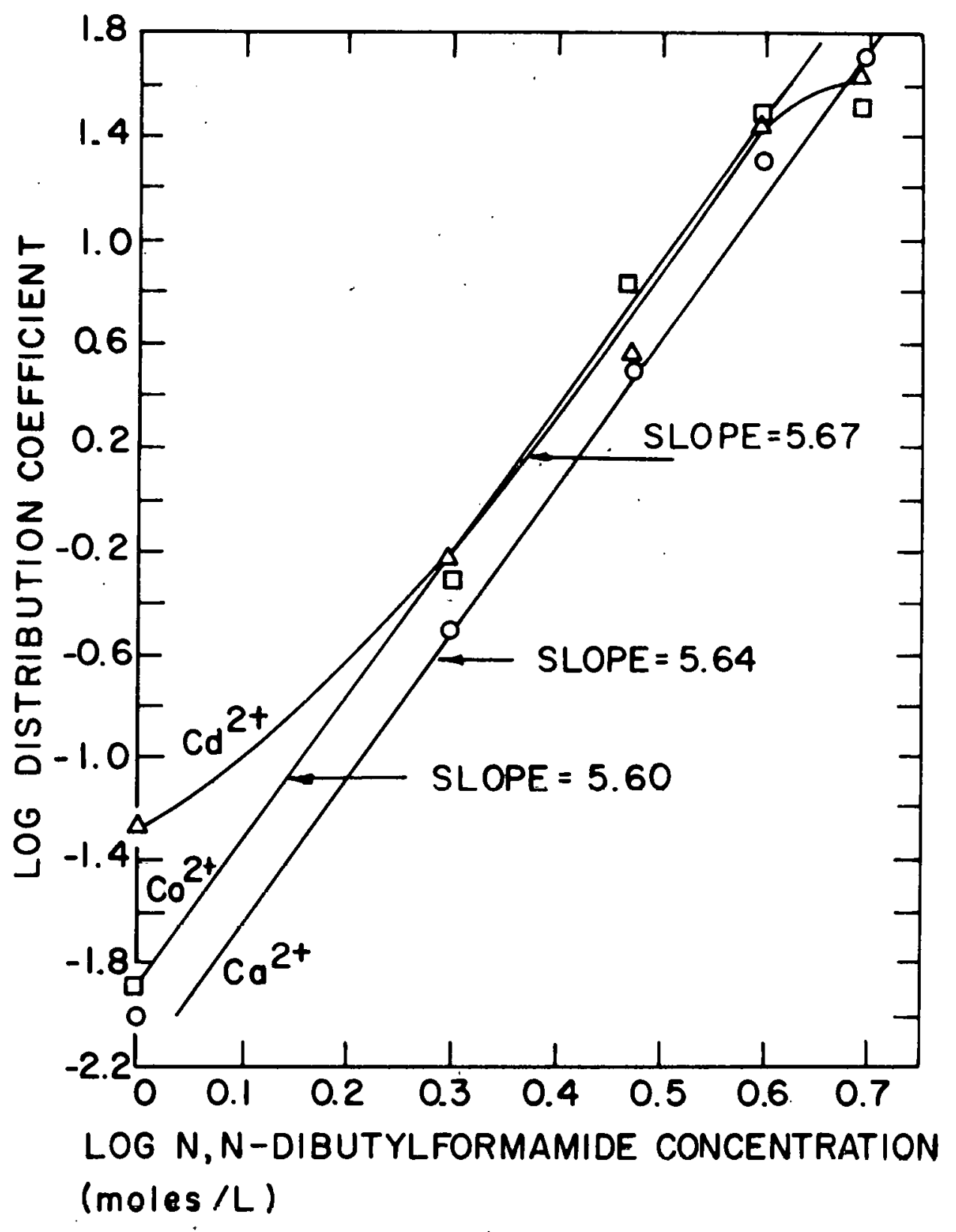

Figure 12. Log distribution coefficient versus log $\mathrm{N}, \mathrm{N}$-dibutylformamide concentration for extraction from perchlorate solution. 


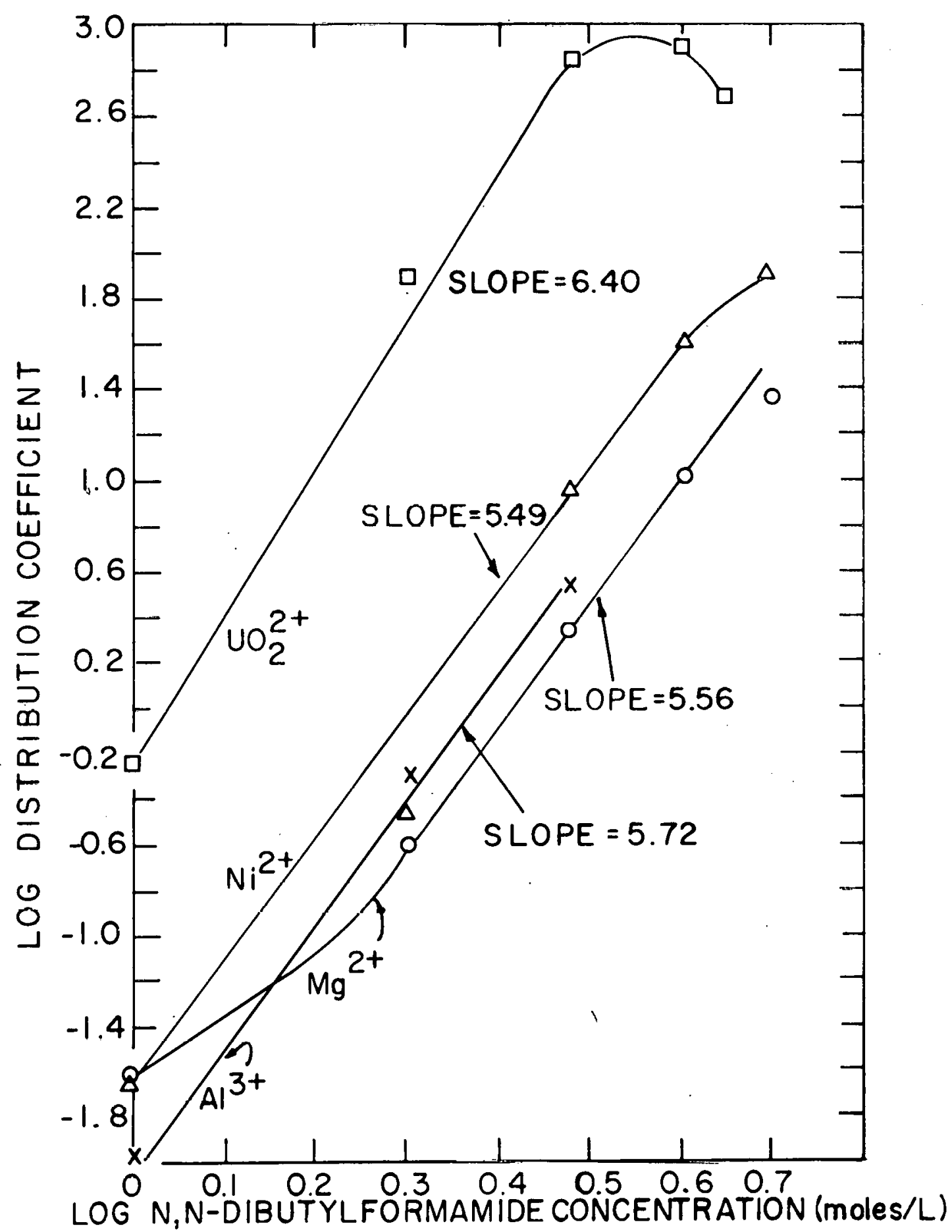

Figure 13. Log distribution coefficient versus log $\mathrm{N}, \mathrm{N}$-dibutylformamide concentration for extraction from perchlorate solution. 


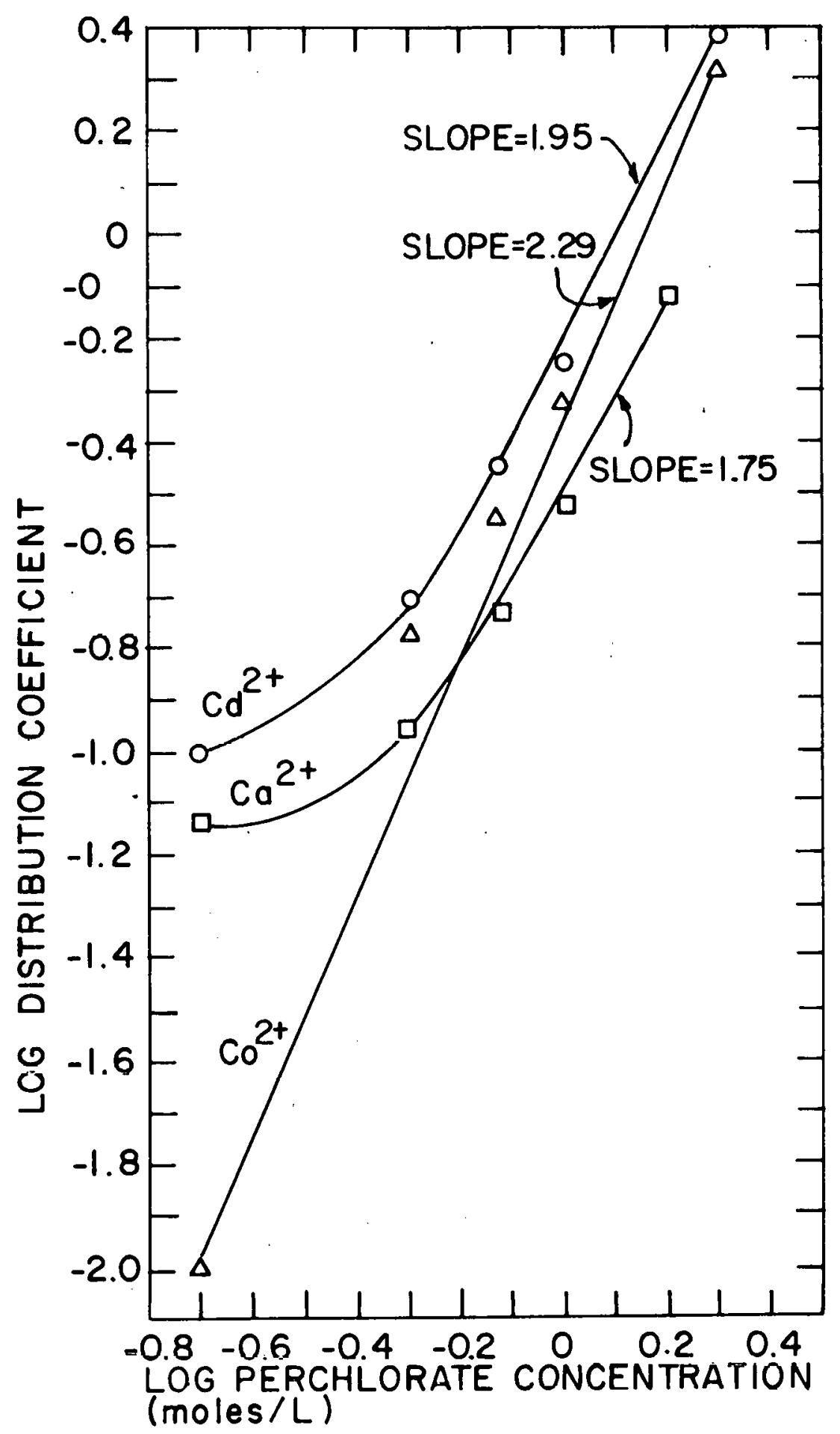

Figure 14. Log distribution coefficient versus log perchlorate concentration for extraction with $\mathrm{N}, \mathrm{N}-$ dibuty lformamide. 


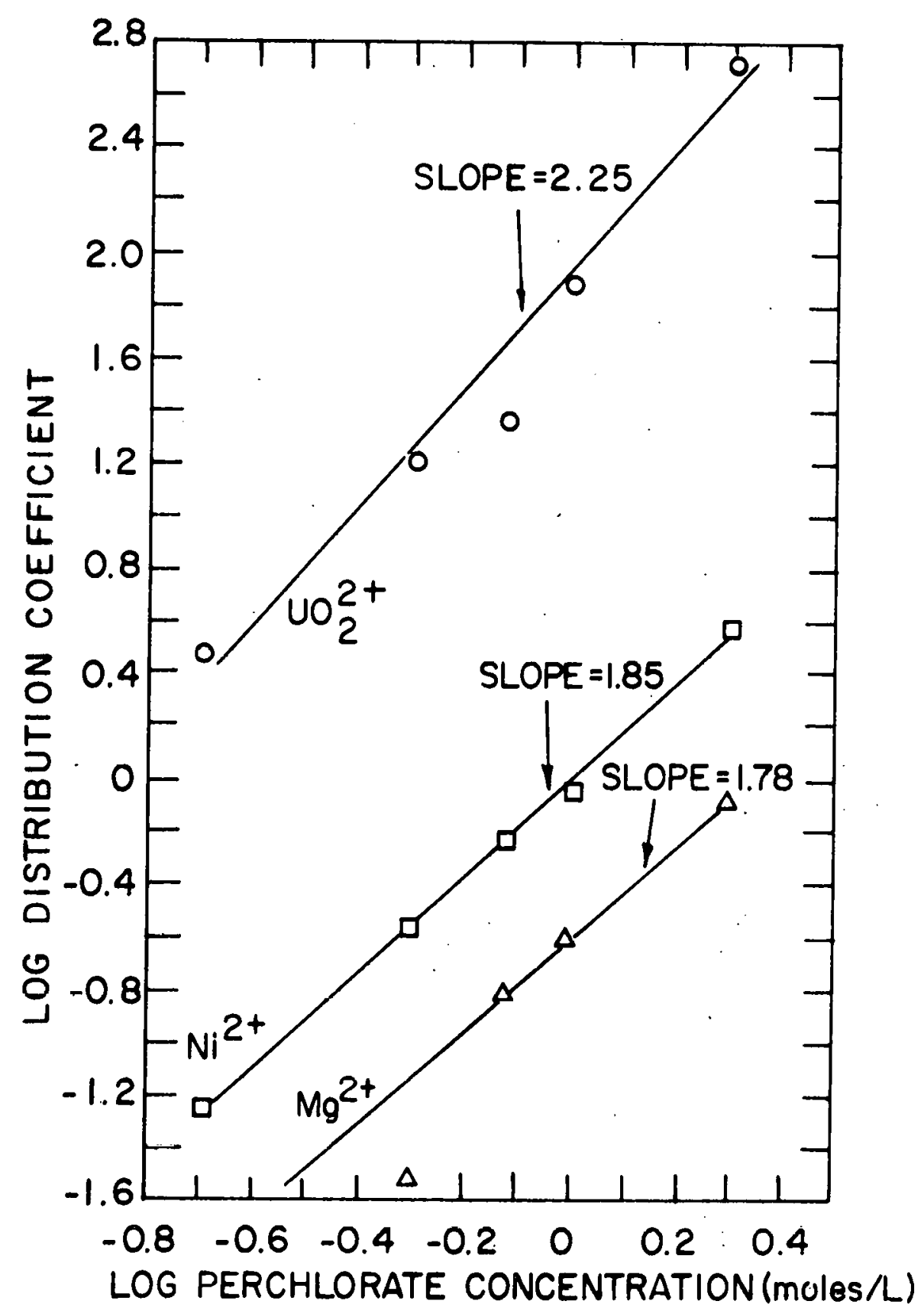

Figure 15. Log distribution coefficient versus log perchlorate concentration for extraction with $\mathrm{N}, \mathrm{N}-$ dibutylformamide. 


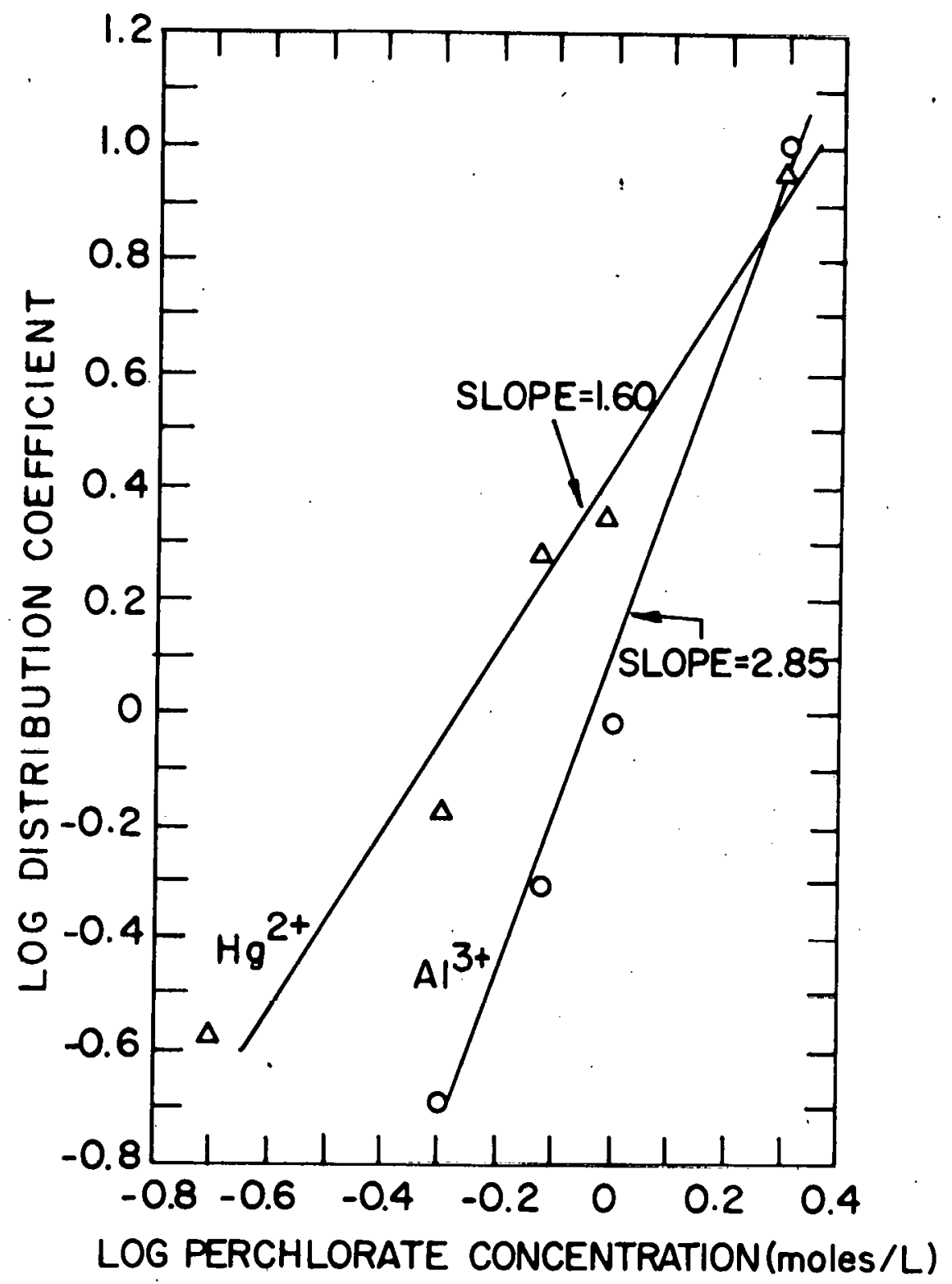

Figure 16. Log distribution coefficient versus log perchlorate concentration for extraction with $\mathrm{N}, \mathrm{N}-$ dibutylformamide. 
THIS PAGE

WAS INTENTIONALLY

LEFT BLANK 
the metal ions were extracted was dependent on the size and the charge of the metal 1on. The highly charged Al, Fe and Th ions were extracted appreciably even at low amide concentrations. The large $\mathrm{Pb}, \mathrm{Hg}, \mathrm{Zr}$, and $\mathrm{U}$ ions were extracted to a much greater extent than smaller ions. In the series Co(II), $\mathrm{Ni}(I I), \mathrm{Cu}(\mathrm{II}), \mathrm{Zn}(\mathrm{II})$ the distribution coefficients followed the Irving-Williams trend, with $\mathrm{Co}($ II $)<\mathrm{Ni}($ II $)<\mathrm{Cu}($ II $)>\mathrm{Zn}($ II $)$. In the series $\mathrm{Zn}(I I), \mathrm{Cd}$ (II), $\mathrm{Hg}$ (II) and $\mathrm{Mg}$ (II), $\mathrm{Ca}$ (II) the distribution coefficients increased with the size of the metal ions.

As with the nitrate system, the separation of uranium, thorium, and zirconium from other metal ions and from each other seems possible. At low perchlorate and DBFA concentrations the separation of $\mathrm{Th}, \mathrm{Zr}$, and $\mathrm{U}$ from all of the other metal ions studied should be possible. As with the nitrate system, DEDA is the most selective solvent for uranium, and it appears that uranium can be separated from all other ions studied with DEDA, regardless of the amide and perchlorate concentrations. The greater selectivity of DEDA than DBFA towards uranium over the other metal ions can be seen in a comparison of the extracting power of $2.0 \mathrm{M} \mathrm{DBFA}$ and DEDA on $\mathrm{Zr}, \mathrm{U}, \mathrm{Th}, \mathrm{Pb}$ and $\mathrm{Fe}$. When extracted from $1.0 \mathrm{M} \mathrm{ClO}^{-}$, the distribution coefficients are as follows, 
DBFA

$$
\mathrm{ZrO}^{+}
$$

UO ${ }_{2}^{2+}$

$\mathrm{Th}^{4+}$

$\mathrm{Pb}^{2+}$

$\mathrm{Fe}^{3+}$ $\infty$

79.0

94.4

1.98

19.47
DEDA

0

20.8

0.78

0

0

A great difference in the distribution coefficients can be noted between DBFA and DEDA for $\mathrm{Zr}$, Th, $\mathrm{Pb}$ and Fe, but the difference between extracting powers is not nearly as great for $U$. The most striking difference between the nitrate and perchlorate systems appears to be with the extraction of zirconium. With the nitrate system, zirconium was extracted appreciably only at high DBFA and nitrate concentrations, and separation of zirconium from other ions appears difficult because other ions are also extracted to a large extent under these conditions. With the perchlorate system zirconium is extracted to a large extent even at Iow DBFA concentrations, and to a much greater extent than the other ions studied. Therefore, the separation of zirconium from all other ions studied appears possible at Iow DBFA and perchlorate concentrations. 


\section{FUTURE WORK}

With the proper choice of conditions it would seem possible to establish several separation schemes with various amides by reversed phase chromatography. Of the amides examined DHAA should prove to be the most appropriate for the separation of $\mathrm{Fe}(\mathrm{III}), \mathrm{Hg}(\mathrm{II}), \mathrm{Th}(\mathrm{IV}), \mathrm{UO}_{2}^{2+}$, and $\mathrm{ZrO}^{2+}$ in nitrate solution. The separation factors between all of these ions extracted from nitrate solution are greater than.2.0; the large hexyl groups on the amide should help hold the amide on the support and help alleviate the problems of bleeding often encountered with reversed phase chromatography.

The amide-perchlorate system would appear to have the potential for the separation of all of the metal ions studied. The separation factors are not as great as those in the nitrate system, but work with different amides than the ones already studied could establish better selectivity.

Feder found that uranium could be back-extracted from the amide by means of an aqueous solution of a complexing agent with a pH value of at least 7 (12). He found that carbonaté, oxalate, or citrate solutions were suitable, and that ammonium carbonate was especially good. Therefore, one of these complexing agents should work well as an eluent for chromatographic separations.

Another possibility for further work would be the synthesis of a resin containing amide functional groups. 
Using Amberlite XAD-2 as the starting material there would be two possibilities for the structure of the amide resin, either as $-\mathrm{CH}_{2}-\mathrm{CH}-\mathrm{CH}_{2}-$ or as $-\mathrm{CH}_{2}-\mathrm{CH}-\mathrm{CH}_{2}-$<smiles>[R]N([R])C(=O)c1ccc(C(C)C)cc1</smiles>

(A)

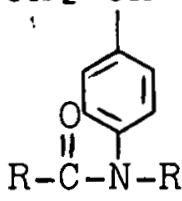

(B)

The first structure should prove to be the better of the two, since the benzene ring should increase the availability of electrons to the oxygen for bond formation. Possible methods for preparing these resins are as follows:

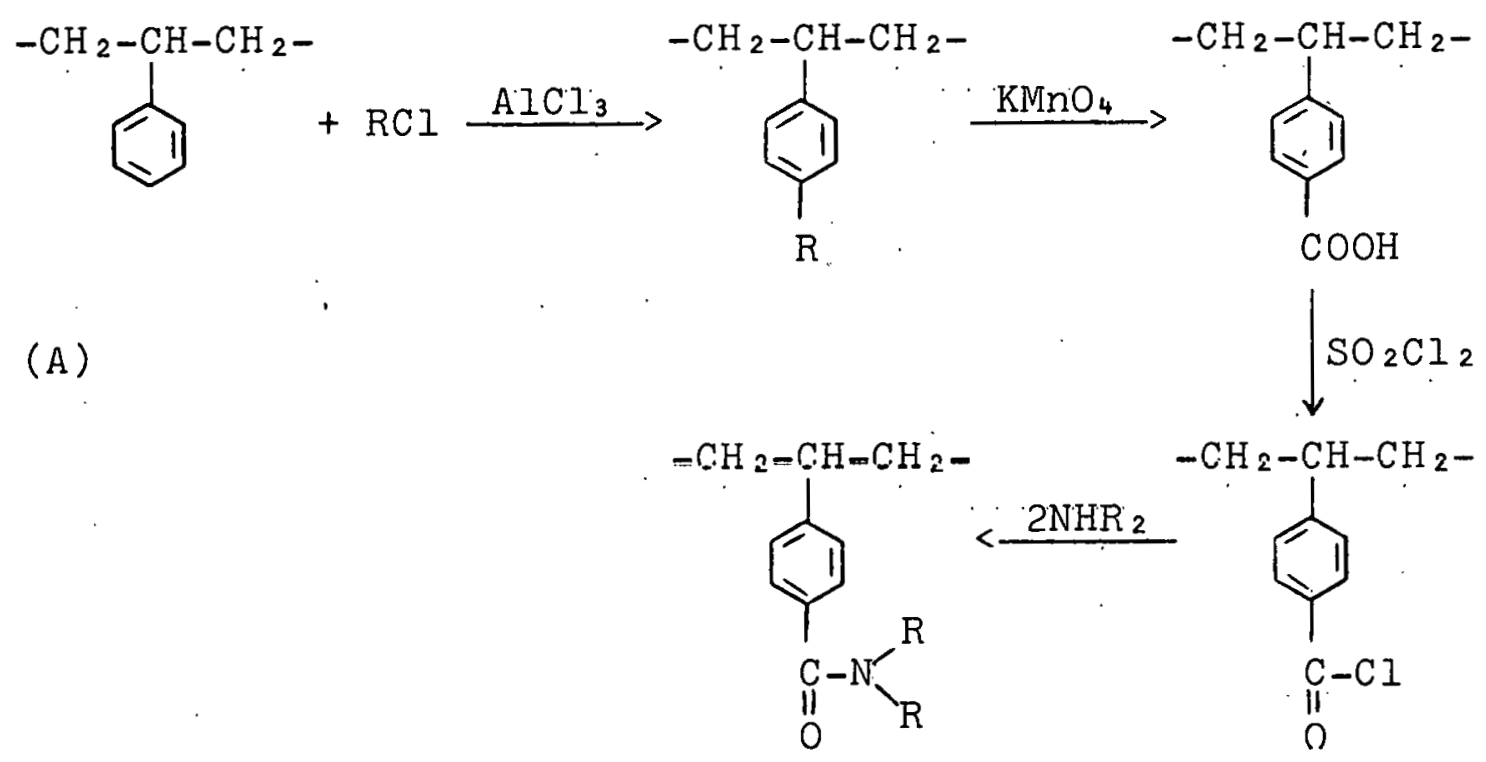


$-\mathrm{CH}_{2}-\mathrm{CH}-\mathrm{CH}_{2}-$

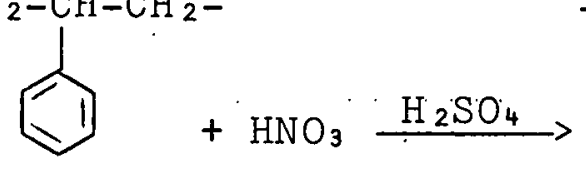

$-\mathrm{CH}_{2}-\mathrm{CH}-\mathrm{CH}_{2}-$

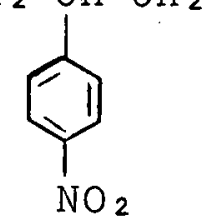

(B)

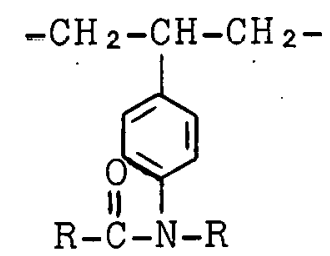

$<(\mathrm{RCO})_{2} \mathrm{O}$

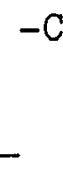<smiles>[R]Nc1ccc(C(C)CCC)cc1</smiles>

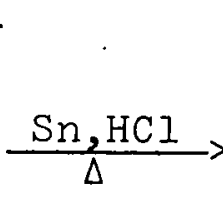

$-\mathrm{CH}_{2}-\mathrm{CH}-\mathrm{CH}_{2}-$

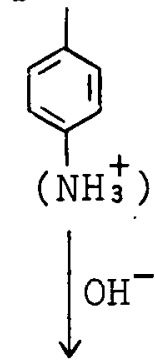

$-\mathrm{CH}_{2}-\mathrm{CH}-\mathrm{CH}_{2}-$

$<-\mathrm{RCI}$<smiles>Cc1ccc(N)cc1</smiles> 
LITERATURE CITED

1. K. Alcock, S. S. Grimley, T. V. Healy, J. Kennedy, and

H. A. McKay, Trans. Faraday Soc. 52, 39 (1956).

2. S. Nomura and R. Hara, Anal. Chim, Acta 25, 212 (1961).

3. D. C. Kennedy and J. S. Fritz, Talanta 17, 823 (1970).

4. G. H. Morrison and H. Freiser, Solvent Extraction in Analytical Chemistry (John Wiley and Sons, New York, 1967).

5. T. H. Siddall, III, USAEC Report No. DP-54I (1961).

6. H. M. Feder, USAEC Report No. ANL-2675, 66 (1951).

7. T. H. Siddall, III, J. Phys. Chem. 64, 1863 (1960).

8. K. B. Brown, C. A. Blake and J.M. Schmitt, USAEC Chem. Technol. Div. Ann. Prog. Rept., ORNL-3452, 178 (1963).

9. K. B. Brown, C. A. Blake and J. H. Schmitt, USAEC Chem. Technol. Div. Chem. Develop. Sect. C Prog. Rept. Separations Chem. and Separations Process Res. ORNL$3496,70(1963)$.

10. W. H. Baldwin, C. E. Higgens and J.M. Schmitt, Chem. Div. Ann. Prog. Rept. ORNL-3679, 56 (1964).

11. USAEC Chem. Div. Ann. Prog. Rept. ORNL-3627, 184 (1964).

12. H. M. Feder and M. Ader, Solvent Extraction of Uranium Values, U. S. Patent 2,872,285 (1959).

13. R. S. Drago, D. W. Meek and M. D. Joesten, Inorg. Chem. 2. $18(1965)$.

14. J. H. Bright, R. S. Drago, D. M. Hart and S. K. Madan, Inorg. Chem. $4,18(1965)$.

15. H. Irving and R. J. P. Williams, J. Chem. Soc. 1949, 1841 (1949).

16. H. Irving, F. S. C. Rossetti and R. J. P. Williams, J. Chem. Soc. 1955, 1906 (1955). 
17. I. M. Kolthoff and P. J. Elving, Treatise on Analytical Chemistry, (Interscience Publishers, New. York, 1961.), part I, vol. 3, p. 1309.

18. H. Irving and R. J. P. Williams, Nature 162, 746 (1948).

19. R. G. Pearson, J. Amer. Chem. Soc. 85, 3533 (1963).

20. N. Bjerrum, Kgl. Danske Selskab I, No. 9 (1926).

21. J. S. Fritz and M. J. Richard, Anal. Chim. Acta 20, 164 (1959).

22. J. S. Fritz, J. E. Abbink and M. A. Payne, Anal. Chem. 33, 1381 (1961). 